\title{
A Review of Austenite Memory Effect in HAZ of B Containing 9\% Cr Martensitic Heat Resistant Steel
}

\author{
Xiaogang $\mathrm{Li}^{1,2}$, Kejian $\mathrm{Li}^{1,2, *}$, Zhipeng Cai ${ }^{1,2,3,4, *}$ and Jiluan Pan ${ }^{1,2}$ \\ 1 Department of Mechanical Engineering, Tsinghua University, Beijing 100084, China; \\ lxg18@mails.tsinghua.edu.cn (X.L.); pjl-dme@tsinghua.edu.cn (J.P.) \\ 2 Key Laboratory for Advanced Materials Processing Technology, Ministry of Education, Beijing 100084, China \\ 3 State Key Laboratory of Tribology, Tsinghua University, Beijing 100084, China \\ 4 Collaborative Innovation Center of Advanced Nuclear Energy Technology, Tsinghua University, \\ Beijing 100084, China \\ * Correspondence: kejianli@mail.tsinghua.edu.cn (K.L.); czpdme@mail.tsinghua.edu (Z.C.)
}

Received: 1 October 2019; Accepted: 13 November 2019; Published: 18 November 2019

\begin{abstract}
During the welding process of B containing 9\% Cr martensitic heat resistant steel (9Cr-B steel), austenite memory effect (referred to that the prior austenite grains in the heat affected zone (HAZ) after welding inherit the shape and size of prior austenite grains before welding) occurs in its normalized sub-zone of HAZ and the grain refinement is suppressed, which can effectively prevent type IV crack, and improve the service life of the welded joint at high temperatures. In the present article, $\alpha / \gamma$ reverse transformation behavior in the normalized sub-zone of $9 \mathrm{Cr}-\mathrm{B}$ steel HAZ is reviewed. Austenite memory effect of $9 \mathrm{Cr}-\mathrm{B}$ steel is derived from $\mathrm{B}$ addition. The main mechanisms of austenite memory effect during $\alpha / \gamma$ reverse transformation are discussed. Various models of boron causing austenite memory effect are discussed in detail. Matrix microstructure also plays an important role in austenite memory effect. Effects of heating rate, peak temperature, and holding time at peak temperature on austenite memory effect are also discussed.
\end{abstract}

Keywords: 9Cr-B steel; heat affected zone (HAZ) microstructure; austenite memory effect; Martensitic reverse transformation; diffusion; retained austenite

\section{Introduction}

9-12\% Cr martensitic heat resistant steels are often used in high-parameter power plants due to their excellent mechanical properties, superior resistance to stress corrosion cracking and oxidation, outstanding performance in machining, as well as low costs [1-7]. Welding is a common technique to fabricate the complex structure or large dimension components of thermal power unit. Because of rapid heating and cooling during welding, non-equilibrium microstructures were formed in heat affected zone (HAZ) [8,9], leading to the degradation of mechanical properties of HAZ and thus weakening the whole welded joint [10]. For the martensitic steel welded joint used in thermal power unit, the service life mainly depended on its creep performance and type IV crack in HAZ was a common creep fracture mode which led to premature failure of the welded joint [11-21]. As they moved away from fusion line, the sub-zones of HAZ of conventional martensitic heat resistant steel, i.e., P91, were classified into coarse-grained HAZ (CGHAZ, also known as overheated sub-zone of HAZ), fine grained HAZ (FGHAZ, also known as normalized sub-zone of HAZ), inter-critical HAZ (ICHAZ) and over-tempered base metal (OTBM), which were distinguished with the different peak temperature and prior austenite grain size [22], as shown in Figure 1 [23]. The formation of sub-zones of HAZ was closely related to the austenitization process during welding. It is well known that $\alpha / \gamma$ reverse transformation in martensitic steels can be by diffusional manner, which means nucleation and growth 
of $\gamma$ are controlled by atom diffusion (i.e., conventional martensitic steel P91), or by shear manner, which means $\alpha$ martensitically transforms to $\gamma$ under a certain orientation relationship without atom diffusion. For conventional martensitic steel, by raising the temperature to $A_{C 1}$, austenite preferentially nucleates at prior austenite grain boundaries, which results from that the high energy at these sites satisfies thermodynamic requirements for $\gamma$ nucleation; and with the temperature increasing, fine austenite grains also nucleate and grow in the interior of prior austenite grains. When the temperature is slightly above $A_{C 3}$, the matrix is completely austenitized, and consists of a large number of fine equiaxial austenite grains, and FGHAZ will form by decreasing the temperature thereafter. If the temperature rises far above $A_{C 3}$, the fine equiaxial austenite grains continue to grow and eventually coarse-grained austenite forms, and after cooling, CGHAZ will form. Type IV crack always occurred in FGHAZ of martensitic steel during service [16-21]. Coarsening of precipitates, lack of adequate precipitates pinning grain boundaries, matrix softening, and grain refinement in FGHAZ contribute to the formation of type IV crack $[13,14,18,24-32]$. Post-weld heat treatment (PWHT) could suppress type IV crack in martensitic steel HAZ [33]. However, for some large or field welding components of thermal power units, PWHT is unpractical. The development of martensitic heat resistant steel without type IV crack is always a research hotspot to avoid premature failure of martensitic steel welded joints.

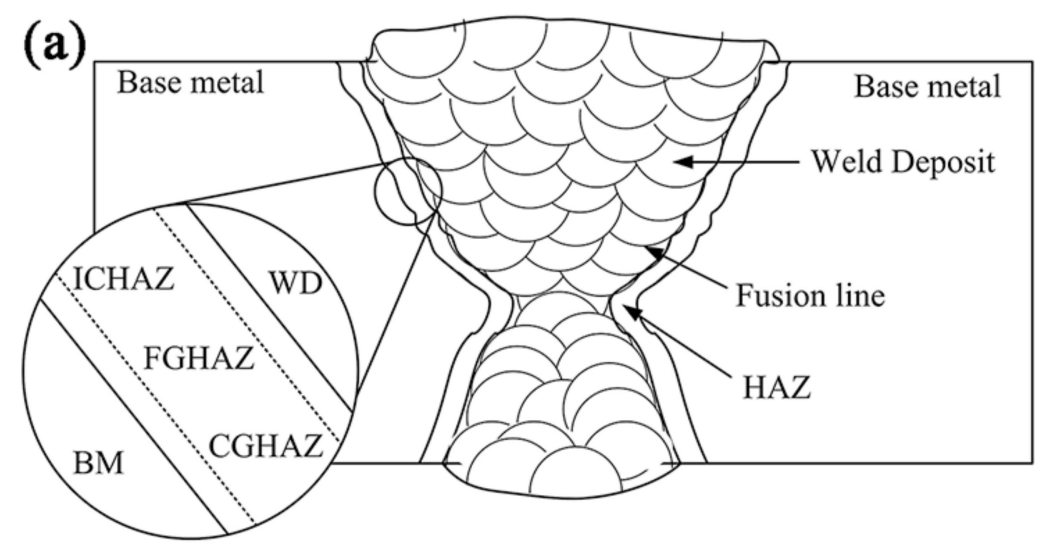

(b)

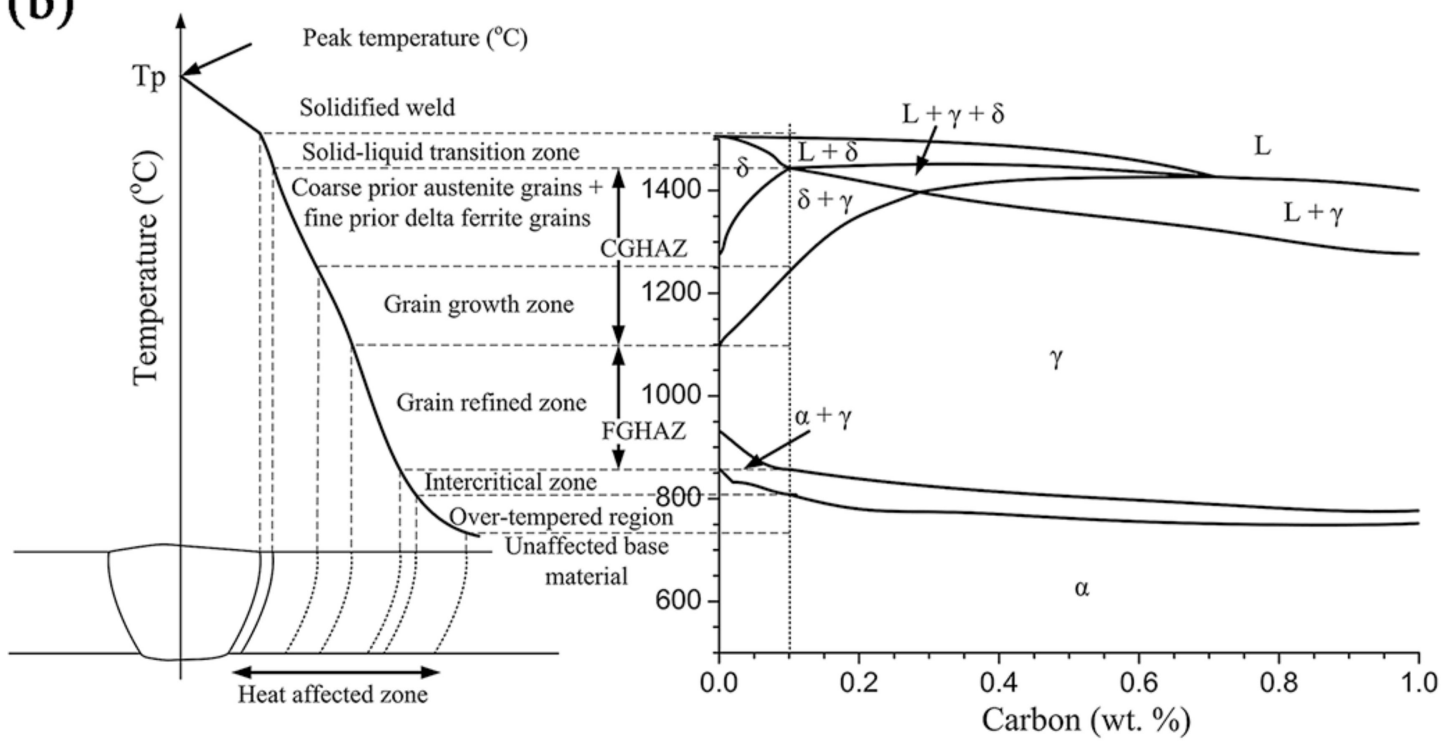

Figure 1. Schematic diagram of P91 heat affected zone (HAZ) [23]: (a) The sub-zones and (b) the corresponding calculated equilibrium phase diagram.

Table 1 shows the developing martensitic heat resistant steels over the years [34,35]. Recently, B containing 9\% Cr martensitic heat resistant steel (9Cr-B steel) with excellent creep property was 
developed, i.e., B containing 9Cr-3W-3Co series steels developed by National Institute for Materials Science (NIMS) in Japan [36-49] and FB2 steel in the frame of the European Cooperation in Science and Technology (COST) program [50-60]. More specially, compared with conventional martensitic steel, the difference of creep strength between base metal and weld joint of 9Cr-B steel was negligible [61], as shown in Figure 2 [62]. Because of the special microstructure in 9Cr-B steel HAZ, there was no type IV crack observed in the welded joint [63]. Normalized sub-zone of HAZ in conventional martensitic steel consists of fine grains, while that of $9 \mathrm{Cr}-\mathrm{B}$ steel consists of grains of which the size is comparable to base metal [64-67], as shown in Figure 3. The suppression of fine-grained microstructure in normalized sub-zone of HAZ was conducive to avoiding type IV fractures and premature failure in the welded joints of $9 \mathrm{Cr}-\mathrm{B}$ steel [66]. The reconstitution of prior austenite grain during austenitization process was reported in $1 \mathrm{Cr}-1 \mathrm{Mo}-0.75 \mathrm{~V}(\mathrm{Ti}, \mathrm{B})$ steel and termed 'austenite memory effect' [68]. In addition, some practical meanings can also be brought by austenite memory effect for weldability. Overheated sub-zone of HAZ of conventional martensitic steel is composed of coarse grains, while that of $9 \mathrm{Cr}-\mathrm{B}$ steel usually consists of fine grains because the austenite of high dislocation density in overheated sub-zone of 9Cr-B steel HAZ would be devoured and transformed into fine austenite at temperature far above $A_{C 3}$. During welding thermal cycle, fine grains could prevent thin film of liquid from connecting in overheated sub-zone of HAZ, implying high resistance to liquation cracking. Fine grains in overheated sub-zone of HAZ are also beneficial to reduce the sensitivity of welding cold crack.

Table 1. Development of $9-12 \%$ Cr martensitic steels $[34,35]$.

\begin{tabular}{ccccc}
\hline Years & $\begin{array}{c}\text { Alloy } \\
\text { Modification }\end{array}$ & $\begin{array}{c}\mathbf{6 0 0}{ }^{\circ} \mathbf{C} / \mathbf{1 0}^{\mathbf{5}} \mathbf{h} \\
\mathbf{C r e e p ~ R e p t u r e} \\
\text { Strength/Mpa }\end{array}$ & Example Alloys & $\begin{array}{c}\text { Maximum } \\
\text { Metal Use } \\
\text { Temperature/ }{ }^{\circ} \mathbf{C}\end{array}$ \\
\hline $1960-1970$ & $\begin{array}{c}\text { Addition of Mo or } \\
\text { Nb, V to simple } \\
12 \mathrm{Cr} \text { and 9Cr steels }\end{array}$ & 60 & $\begin{array}{c}\text { EM12, HCM9M, HT9, } \\
\text { Tempaloy F9, HT 91 }\end{array}$ & 565 \\
\hline $1970-1985$ & $\begin{array}{c}\text { Optimization of C } \\
\text { Nb, V }\end{array}$ & 100 & HCM12, T91, HCM2S & 593 \\
\hline $1985-1995$ & $\begin{array}{c}\text { Partial substitution } \\
\text { of W for Mo }\end{array}$ & 130 & $\begin{array}{c}\text { P92, P122, P911 (NF 616, } \\
\text { HCM12A) }\end{array}$ & 620 \\
\hline \multirow{2}{*}{ Emerging } & $\begin{array}{c}\text { Increase W and } \\
\text { addition of Co, B } \\
\text { and controlled N }\end{array}$ & 150 & $\begin{array}{c}\text { NF12, SAVE 12, MARN, } \\
\text { MARB2, MARBN }\end{array}$ & 650 \\
\hline
\end{tabular}

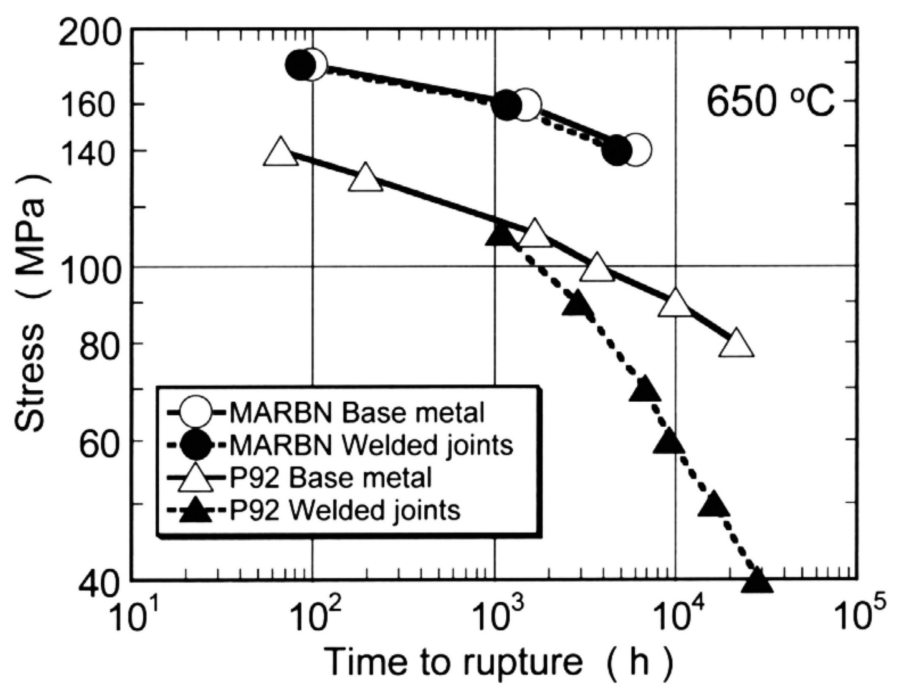

Figure 2. Creep strength of base metals and welded joints of conventional martensitic steel P92 and NIMS 9Cr-B steel MARBN at $650{ }^{\circ} \mathrm{C}$ [62]. 


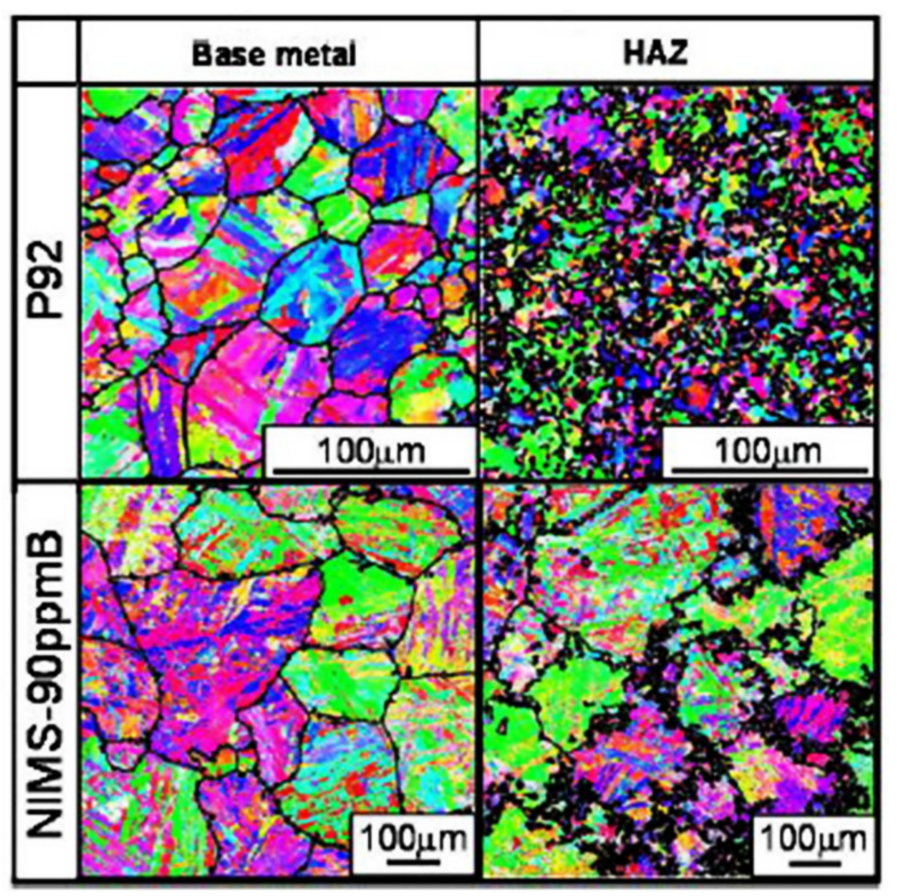

Figure 3. Comparison of grain size in base metals and HAZs of conventional martensitic steel P92 and NIMS 130B 9Cr-3W-3Co steel, using electron backscatter diffraction (ESBD) [66].

For 9Cr-B steel, the mechanism for austenite memory effect has not yet been clarified, and in the present article some literatures about austenite memory effect in welding process of 9Cr-B steel are reviewed. The mechanisms and factors influencing austenite memory effect in 9Cr-B steel HAZ are summarized, and the microstructure evolution during austenitization process is critically analyzed to provide guidance for future research about the formation of HAZ during the welding of martensitic steel.

\section{Mechanisms of Austenite Memory Effect in 9Cr-B Steel HAZ}

\subsection{Martensitic Reverse Transformation}

Martensitic $\alpha / \gamma$ reverse transformation took place during heating of $18 \%$ Ni maraging steel [69], as shown in Figure 4a. Coarse prior austenite surrounded by some fine prior austenite was observed in $A_{\mathrm{C} 3} \mathrm{HAZ}$ (normalized sub-zone of HAZ) simulated sample of NIMS B containing 9Cr-3W-3Co steel $[41,70]$, as shown in Figure 4a. The newly formed coarse prior austenite was reconstituted from the original prior austenite in matrix, which meant that austenite memory effect occurred during heating, and then they transformed into martensite with almost the same crystal orientation as original martensite after cooling [63], as shown in Figure 4b. Shirane et al. [69] believed that there were two stages during $\alpha / \gamma$ reverse transformation in $A_{\mathrm{C} 3} \mathrm{HAZ}$ of 130B 9Cr-3W-3Co steel: (i) Formation of fine austenite by diffusional transformation at prior austenite grain boundary; (ii) martensitic $\alpha / \gamma$ reverse transformation in interior of prior austenite grain. Abe et al. [71,72] claimed that in $9 \mathrm{Cr}-\mathrm{B}$ steel, the segregation of boron at prior austenite grain boundaries delayed diffusional phase transformation at these sites and hence promoted martensitic $\alpha / \gamma$ reverse transformation. The martensitic $\alpha / \gamma$ reverse transformation led to the reconstruction of the original prior austenite in 9Cr-B steel [70] due to the Kurdjumov-Sachs orientation relationship between the newly formed austenite and its adjacent martensite [73,74]. During the whole $\alpha / \gamma$ reverse transformation of $18 \mathrm{Ni}-6 \mathrm{Mo}-9 \mathrm{Co}$ maraging steel, there was obvious blocky surface relief [70], which was a typical indicator of martensitic reverse transformation. For 130B 9Cr-3W-3Co steel, $\alpha / \gamma$ reverse transformation without surface relief firstly occurred at prior austenite grain boundary [70], corresponding to the formation of fine austenite by 
diffusion; then, the martensite in interior of prior austenite grain transformed to austenite with surface relief [70], corresponding to the formation of coarse austenite by shear.

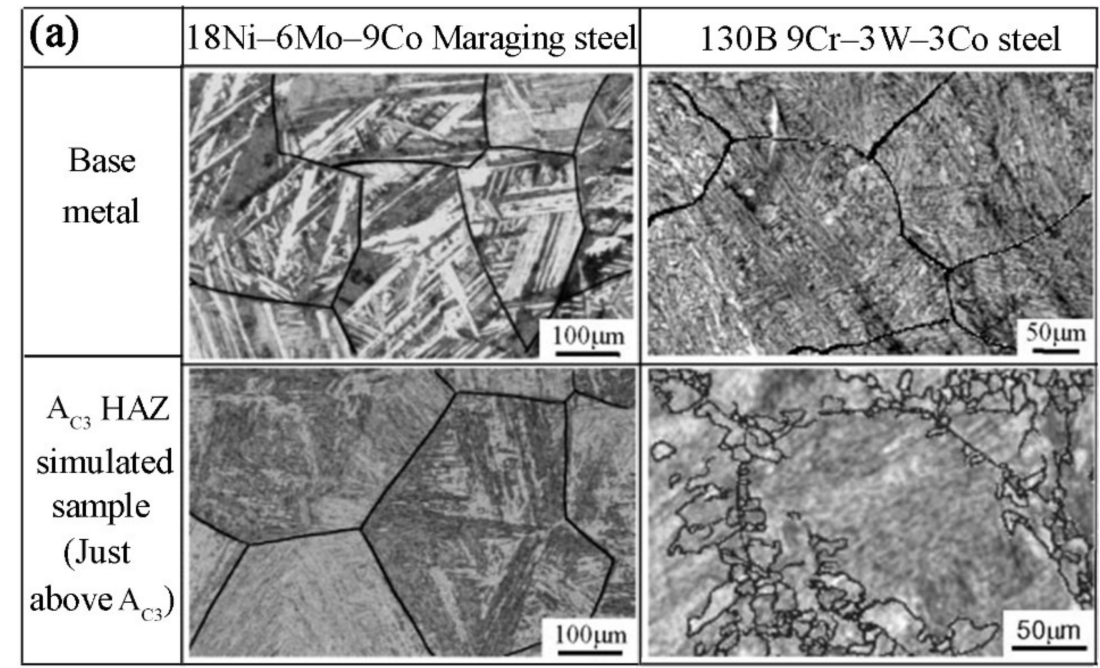

(b)
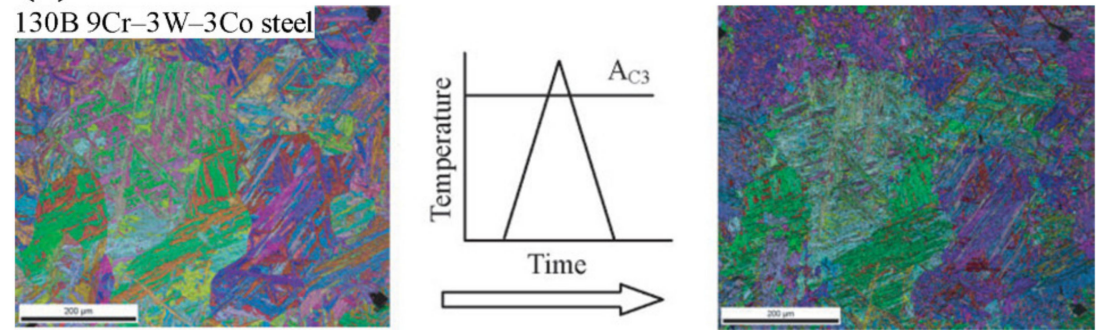

Figure 4. Microstructure of base metals and simulated $A_{\mathrm{C} 3} \mathrm{HAZs}$ of $18 \mathrm{Ni}-6 \mathrm{Mo}-9 \mathrm{Co}$ maraging steel and NIMS 130B 9Cr-3W-3Co steel [70]: (a) Scanning electron microscopy (SEM) images and (b) EBSD images.

\subsection{Restricting Austenite Growth by Precipitate}

Das et al. [75] found that the crept welded joint of P91 ruptured in ICHAZ, which was type IV failure, while that of boron modified P91 (P91B, P91 containing 100 ppm boron) fractured from weld metal to ICHAZ, which was a sign of type II failure, indicating that appropriate amount of boron could strengthen the microstructure of $\mathrm{HAZ}$ and change the failure mode of $9 \% \mathrm{Cr}$ steel welded joint. Different from the fine austenite in P91 FCHAZ/ICHAZ, there were mainly coarse prior austenite grains in P91B HAZ, which resulted from austenite memory effect caused by adding boron [76]. Das et al. $[75,76]$ also believed that fine austenite firstly nucleated by diffusion at prior austenite grain boundary during austenization process, but they proposed different formation mechanism of coarse austenite in interior of prior austenite grain. Boron enhanced stability of the precipitates at martensite lath boundaries and made the precipitates at these sites difficult to dissolve at high temperature $[75,76]$, as shown in Figure 5a. During $\alpha / \gamma$ reverse transformation, the precipitates continuously distributed along martensite lath boundaries were regarded as "wall" and the diffusion growth of austenite was restricted. The newly formed austenite could only grow along the direction of martensite lath extension and not get through martensite lath boundary, as shown in Figure 5b, and finally the original prior austenite grains were reconstituted. Shirane et al. [70] claimed that formation of coarse-grained austenite was controlled by shear and the surface relief was observed by a confocal scanning laser microscope to prove their view. However, the presence of surface relief did not contradict the mechanism of restricting diffusion growth of austenite because morphology of austenite formed by this mechanism was consistent with martensite lath and there might be surface relief during austenitizing. 
(a)
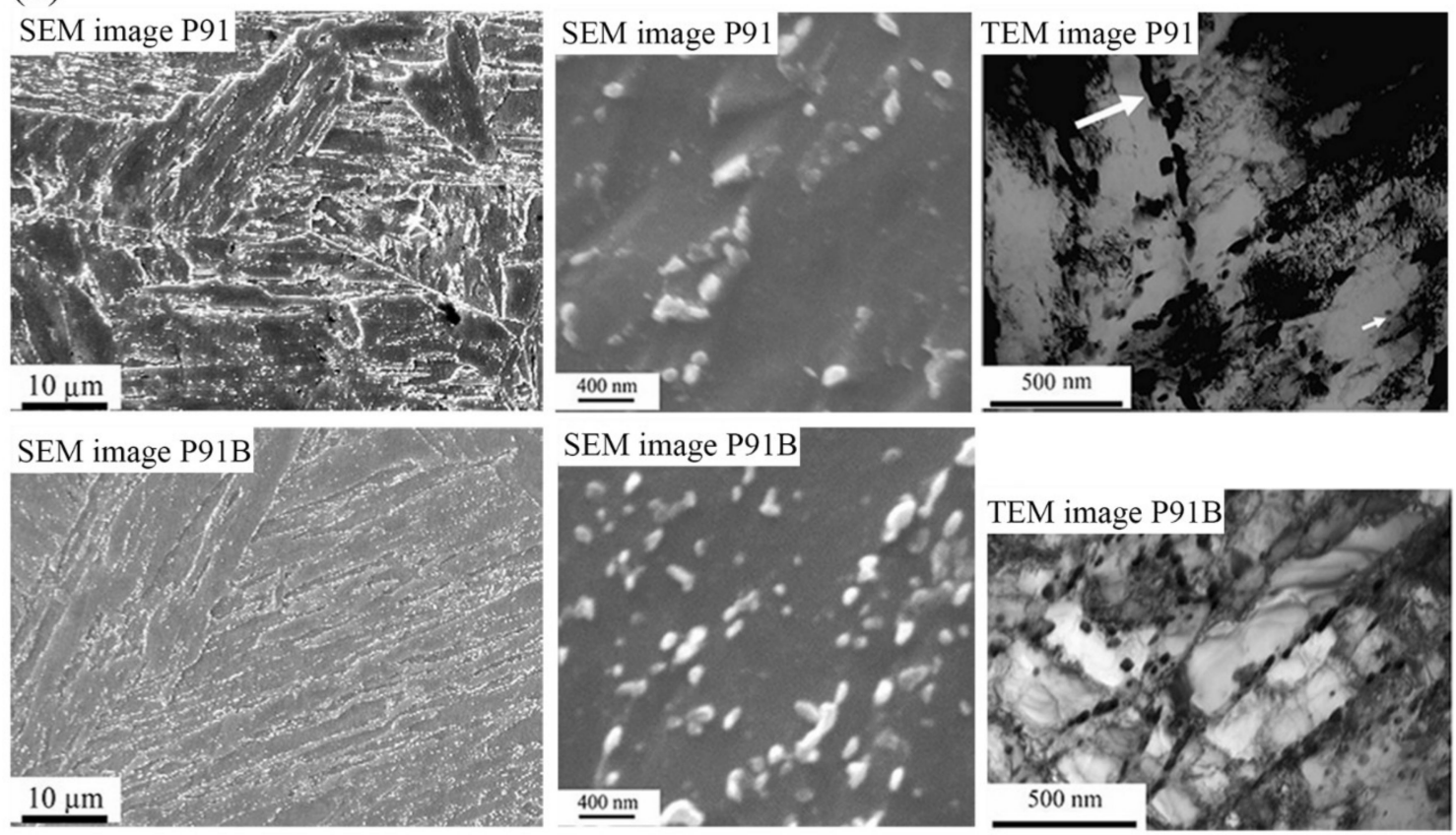

(b)

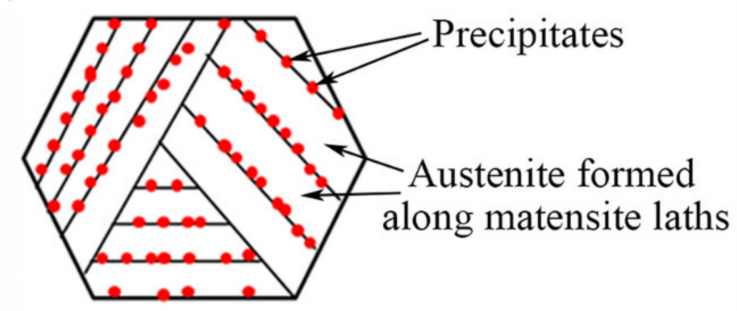

Figure 5. Microstructure of $\mathrm{P} 91$ and $\mathrm{P} 91 \mathrm{~B}$, and the mechanism of restricting austenite growth by precipitate: (a) SEM and TEM images of base metals normalized at $1150{ }^{\circ} \mathrm{C}$ and tempered at $760{ }^{\circ} \mathrm{C}$ for $3 \mathrm{~h} \mathrm{[75]} \mathrm{and} \mathrm{(b)} \mathrm{schematic} \mathrm{diagram} \mathrm{of} \mathrm{restricted} \mathrm{austenite} \mathrm{growth.}$

\subsection{Growth and Coalescence of Retained Austenite}

Shirane et al. [70] omitted the tempering process of NIMS 130B 9Cr-3W-3Co steel to retain $1.9 \%$ austenite in matrix, and they found that coarse grains were also observed in $A_{\mathrm{C} 3} \mathrm{HAZ}$ simulated sample, as shown in Figure 6a, indicating that austenite memory effect occurred during $\alpha / \gamma$ reverse transformation; however, no fine austenite was found at coarse austenite grain boundaries, which was different from $A_{\mathrm{C} 3} \mathrm{HAZ}$ simulated sample of 130B 9Cr-3W-3Co steel without retained austenite. In retained austenite containing $9 \mathrm{Cr}-\mathrm{B}$ steel, mechanism of austenite memory effect was growth and coalescence of retained austenite in manner of diffusion, which was similar to the $\alpha / \gamma$ reverse transformation in $13 \mathrm{Cr}-5 \mathrm{Ni}$ martensitic steel $[77,78]$. Figure $6 \mathrm{~b}$ shows the process of growth and coalescence of retained austenite. Firstly, fine austenite was formed at original prior austenite grain boundary through diffusional transformation. Meanwhile, the retained austenite grains in the interior of the original prior austenite grew. The retained austenite was untransformed original prior austenite and its orientation was same with that of original prior austenite. Therefore, with the rise in temperature, the growing retained austenite grains impinged, and could then coalesce. As the temperature increased above $A_{C 3}$, the original prior austenite was reconstituted and coarse austenite was formed. In particular, fine austenite at prior austenite grain boundaries was absorbed by coarse austenite and eventually disappeared completely when the austenitization process was completed. 
(a)

130B 9Cr-3W-3Co steel with retained austenite (obtained by omitting tempering)

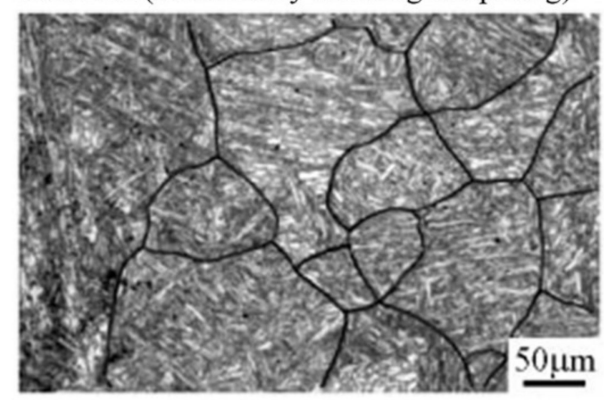

$13 \mathrm{Cr}-5 \mathrm{Ni}$ Martensitic steel

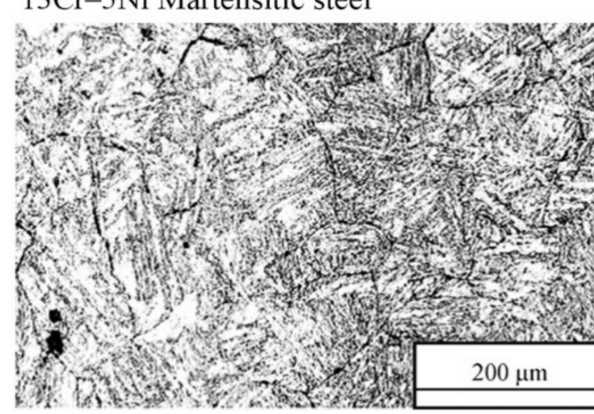

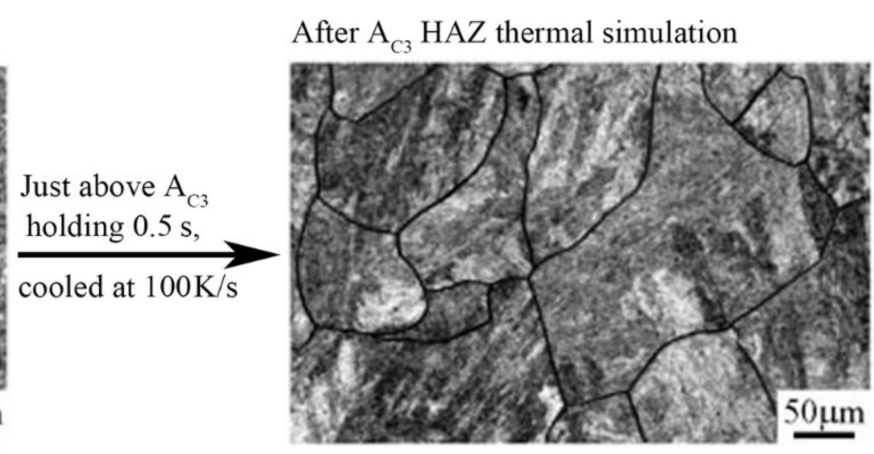

After isothermal reverse transformation

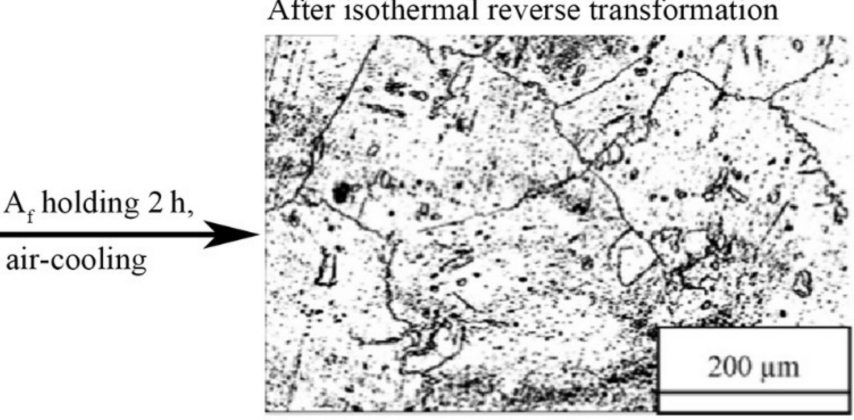

(b)

As received

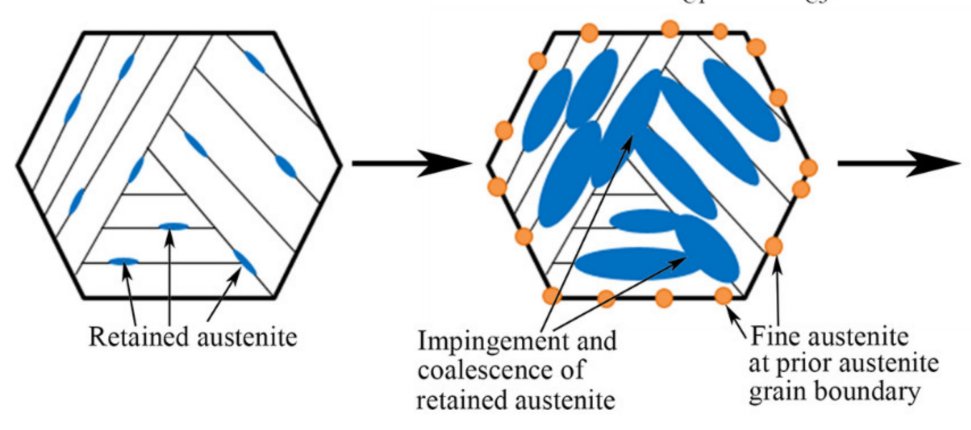

Above $\mathrm{A}_{\mathrm{C} 3}$

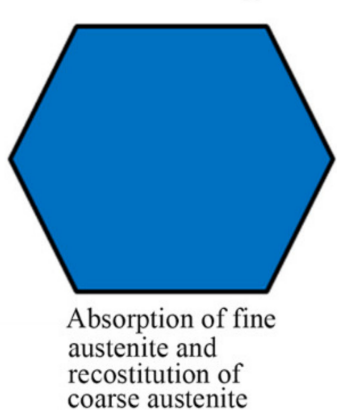

Figure 6. Austenite memory effect in containing retained austenite martensitic steel: (a) SEM images of containing 1.9\% retained austenite 130B 9Cr-3W-3Co steel [70] and 13Cr-5Ni martensitic steel [77] and (b) schematic diagram of mechanism of retained austenite growth and coalescence.

\section{Factors Affecting Austenite Memory Effect in 9Cr-B Steel HAZ}

\subsection{Boron Element}

Table 2 shows the chemical compositions of steels reported in this article. Shirane et al. [70] reduced boron content in NIMS 130B 9Cr-3W-3Co steel to a very low level (1 ppm) and found the grain refinement again in HAZ, which meant that austenite memory effect was closely related to boron. There were three main models for boron promoting austenite memory effect in normalized sub-zone of 9Cr-B steel HAZ, proposed by Abe et al. [71,72], us [79,80], and Das et al. [75,76]. These models were discussed in more detail in the following section. 
Table 2. The chemical compositions of steel grades reported in the present article (Wt-\%).

\begin{tabular}{|c|c|c|c|c|c|c|c|c|c|}
\hline Elements & $\mathrm{C}$ & $\mathrm{Cr}$ & Mo & Mn & Si & $\mathbf{N i}$ & Co & $\mathbf{W}$ & $\mathbf{V}$ \\
\hline NIMS 130B steel [70] & 0.077 & 8.97 & - & 0.49 & 0.300 & - & 2.91 & 2.87 & 0.18 \\
\hline NIMS 90B steel [72] & 0.074 & 8.93 & - & 0.48 & 0.3 & - & 2.92 & 3.13 & 0.18 \\
\hline MARBN [72] & 0.079 & 8.81 & - & 0.51 & 0.31 & - & 3.10 & 3.05 & 0.20 \\
\hline Maraging steel [70] & 0.003 & - & 5.80 & 0.02 & 0.006 & 18.5 & 8.57 & - & - \\
\hline P91B [75] & 0.100 & 8.500 & 1.040 & 0.300 & 0.400 & 0.020 & - & - & 0.230 \\
\hline P91 [75] & 0.100 & 9.500 & 1.000 & 0.390 & 0.480 & 0.140 & - & - & 0.250 \\
\hline $\begin{array}{c}13 \mathrm{Cr}-5 \mathrm{Ni} \text { Martensitic } \\
\text { steel [77] }\end{array}$ & 0.04 & 12.87 & 1.36 & 0.55 & 0.14 & 5.01 & - & - & 0.03 \\
\hline P92 $[66]$ & 0.09 & 8.72 & 0.45 & 0.47 & 0.16 & - & - & 1.87 & 0.21 \\
\hline Gr.92 [72] & 0.09 & 8.72 & 0.45 & 0.47 & 0.16 & - & - & 1.87 & 0.21 \\
\hline FB2 [79] & 0.13 & 9.30 & 1.5 & 0.40 & 0.05 & 0.15 & 1.0 & - & 0.2 \\
\hline Elements & $\mathrm{Nb}$ & $\mathrm{Al}$ & $\mathrm{Cu}$ & $\mathrm{Ti}$ & $\mathrm{P}$ & $S$ & $\mathrm{~N}$ & B & $\mathrm{Fe}$ \\
\hline NIMS 130B steel [70] & 0.05 & - & - & - & - & - & 0.0015 & 0.0130 & Balance \\
\hline NIMS 90B steel [72] & 0.046 & - & - & - & - & - & 0.0014 & 0.009 & Balance \\
\hline MARBN [72] & 0.055 & - & - & - & - & - & 0.085 & 0.016 & Balance \\
\hline Maraging steel [70] & - & - & - & 0.72 & - & - & - & - & Balance \\
\hline P91B [75] & 0.090 & 0.030 & - & - & 0.005 & 0.002 & 0.002 & 0.010 & Balance \\
\hline P91 [75] & 0.100 & 0.024 & - & - & 0.021 & 0.009 & 0.065 & - & Balance \\
\hline $\begin{array}{c}\text { 13Cr-5Ni Martensitic } \\
\text { steel [77] }\end{array}$ & - & - & 0.04 & - & 0.01 & 0.02 & 0.06 & - & Balance \\
\hline P92 [66] & 0.06 & - & - & - & - & - & 0.050 & 0.002 & Balance \\
\hline Gr.92 [72] & 0.06 & - & - & - & - & - & 0.05 & 0.002 & Balance \\
\hline FB2 [79] & 0.05 & - & - & - & - & - & 0.02 & 0.01 & Balance \\
\hline
\end{tabular}

Effect of boron on austenite memory effect in normalized sub-zone of NIMS 130B 9Cr-3W-3Co steel HAZ was explained by Abe et al. as follows [72]. Figure 7 diagrammatically shows the microstructure evolution in conventional martensitic steel Gr.92 and 130B 9Cr-3W-3Co steel during $A_{C 3}$ HAZ thermal simulation. In the austenitization process of Gr.92, fine austenite grains nucleated and grew by diffusion and the grain refinement appeared when peak temperature reached $A_{C 3}$. Abe [81] estimated the equilibrium grain boundary segregation of boron. It was assumed that initially boron was distributed homogeneously in matrix with the concentration $C_{i}$, as shown in Figure 8a. When equilibrium grain boundary segregation was achieved, boron concentration at grain boundary $C_{G B}$ was described as.

$$
C_{\mathrm{GB}}=C_{0} \exp (B / R T)
$$

where $C_{0}$ is the boron concentration in the interior of the grain, $B$ the binding energy between the boron and grain boundary, $R$ the gas constant, and $T$ the absolute temperature. The total boron atoms was equal to the sum of boron atoms at grain boundary and in interior of grain, which could be described as:

$$
\left\{\pi r_{0}^{2}-\pi\left(r_{0}-\delta\right)^{2}\right\} C_{\mathrm{GB}}+\pi\left(r_{0}-\delta\right)^{2} C_{0}=\pi r_{0}^{2} C_{\mathrm{i}}
$$

where $r_{0}$ is the grain radius, $\delta$ the width of grain boundary, and $C_{i}$ the initial boron concentration. According to Equations (1) and (2), Abe [81] obtained:

$$
C_{0}=\pi r_{0}^{2} C_{\mathrm{i}} /\left[\left\{\pi r_{0}^{2}-\pi\left(r_{0}-\delta\right)^{2}\right\} \exp (B / R T)+\pi\left(r_{0}-\delta\right)^{2}\right]
$$




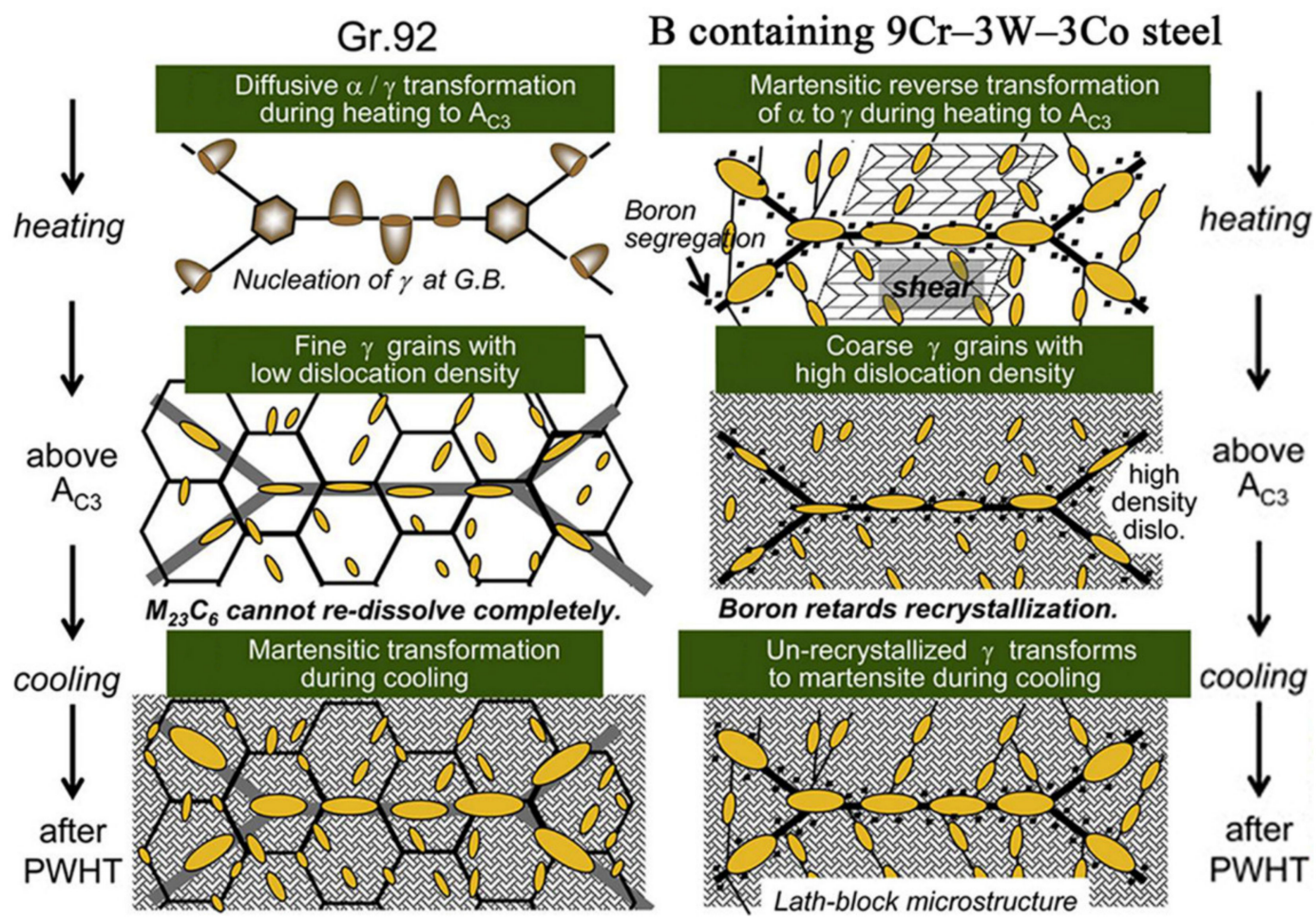

Figure 7. Schematic diagram of microstructure evolution in Gr.92 and 130B 9Cr-3W-3Co steel during $A_{C 3}$ HAZ thermal simulation [72].

(a)

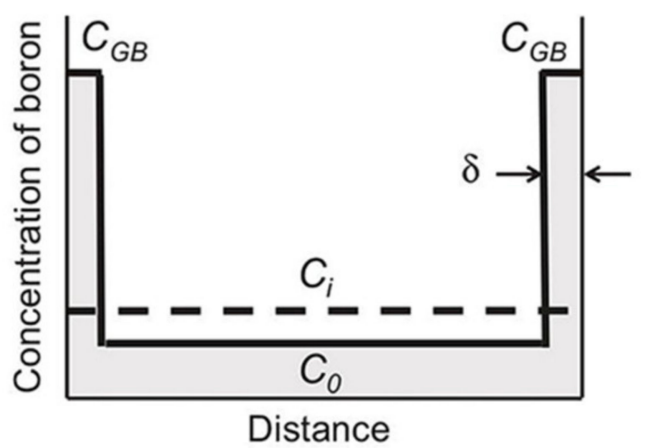

(b)

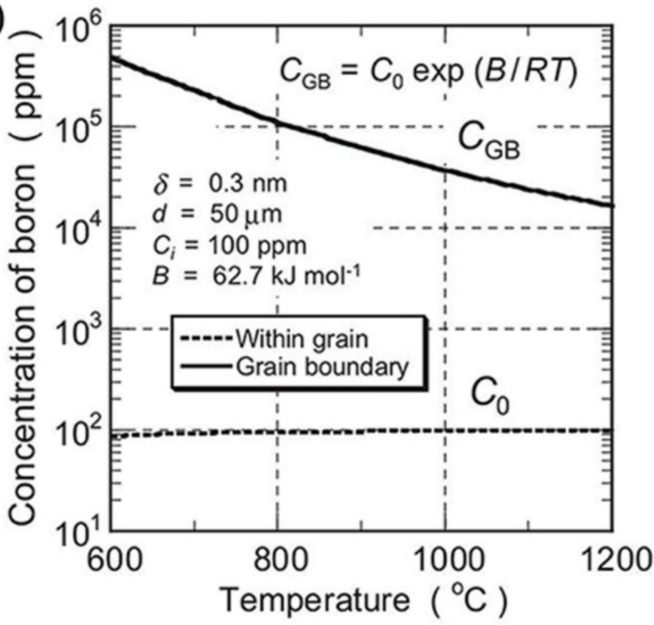

Figure 8. (a) Boron concentration profile [81] and (b) boron concentration at grain boundary $\left(C_{G B}\right)$ and in interior of grain $\left(C_{0}\right)$ vs. temperature [81].

Assuming the grain size of $50 \mu \mathrm{m}$ and $C_{i}$ of $100 \mathrm{ppm}$ and picking binding energy of $62.7 \mathrm{~kJ} \mathrm{~mol}^{-1}$ reported for 316 stainless steel, Abe [81] got $C_{0}$ and $C_{G B}$ as a function of temperature, as shown in Figure $8 \mathrm{~b}$. For NIMS B containing $9 \mathrm{Cr}-3 \mathrm{~W}-3 \mathrm{Co}$ series steels at normalizing temperature of around $1100{ }^{\circ} \mathrm{C}$ and tempering temperature of around $800{ }^{\circ} \mathrm{C}$, there would be boron segregation at grain boundaries [81]. $\alpha / \gamma$ reverse transformation in $18 \mathrm{Ni}$ maraging steel was typically martensitic [82]. Abe [63] believed during heating of $9 \mathrm{Cr}-\mathrm{B}$ steel, the boron segregation at the grain boundaries lowered the grain boundary energy and the heterogeneous nucleation at these sites was retarded, resulting in martensitic $\alpha / \gamma$ reverse transformation, as shown in Figure 7. At a heating rate of $100 \mathrm{~K} / \mathrm{s}, A_{\mathrm{C} 1}$ temperature of $841^{\circ} \mathrm{C}$ for $90 \mathrm{~B} 9 \mathrm{Cr}-3 \mathrm{~W}-3 \mathrm{C}$ o steel was higher than that of $817^{\circ} \mathrm{C}$ for P92, which might be related with boron retardation effect on diffusional $\alpha / \gamma$ reverse transformation [72]. In addition, 
Santella et al. [83] used a synchrotron diffraction system to examine real-time $\alpha / \gamma$ reverse transformation in HAZ simulated samples of 130B 9Cr-3W-3Co steel $\left(A_{C 1} 841^{\circ} \mathrm{C}, A_{\mathrm{C} 3} 920^{\circ} \mathrm{C}\right)$ and $\mathrm{P} 92\left(A_{\mathrm{C} 1} 817^{\circ} \mathrm{C}, A_{\mathrm{C} 3}\right.$ $912^{\circ} \mathrm{C}$ ), and they found: When heated to a peak temperature of approximately $1100{ }^{\circ} \mathrm{C}$, all martensite in both steels transformed to austenite; when peak temperatures for 130B 9Cr-3W-3Co steel and P92 were $911^{\circ} \mathrm{C}$ and $896{ }^{\circ} \mathrm{C}$, respectively, about $44 \%$ and $85 \%$ of martensite in $130 \mathrm{~B} 9 \mathrm{Cr}-3 \mathrm{~W}-3 \mathrm{Co}$ steel and P92 transformed to austenite, which was another indicator of inhibition of $\alpha / \gamma$ reverse transformation in 130B 9Cr-3W-3Co steel compared with P92. In particular, Gr.92 contained 20 ppm boron but did not present austenite memory effect during heating, which was related to the formation of BN due to high nitrogen concentration of 500 ppm in Gr.92. Sakuraya et al. [84] observed a large number of BN particles on Gr.92 fracture appearance. The trigger for boron promoting austenite memory effect was that there was a certain amount of solid solution boron rather than BN in steel. Abe et al. [72] investigated the influence of boron and nitrogen concentrations on grain refinement behavior in $9 \% \mathrm{Cr}$ steels during heating between $900{ }^{\circ} \mathrm{C}$ and $1100{ }^{\circ} \mathrm{C}$ and overlapped it on the $\mathrm{BN}$ formation composition diagram during normalizing process [85].

Our previous researches $[79,80,86]$ have shown that for FB2 steel, grain size in the normalized sub-zone of HAZ was equal to that in base metal and the grains in the overheated sub-zone of HAZ were much finer than those in the base metal. We [80] preliminarily confirmed the formation of fine austenite around precipitates at martensite lath boundary, which was a further supplement to austenitization process in 9Cr-B steel HAZ. Figure 9a shows the microstructures of the same location before and after $A_{C 3} \mathrm{HAZ}$ thermal simulation of FB2. Prior austenite grains remained relatively intact without obvious movement of grain boundary and change of martensite lath orientation. Apple and Krauss [87] found that the interface of prior austenite grain formed by martensitic-type transformation was relatively straight, while that formed by diffusional-type transformation was rounded in the austenitization process of Fe-Ni-C alloy. During $\alpha / \gamma$ reverse transformation in normalized sub-zone of FB2 HAZ, fine austenite with rounded interface (marked by arrows in Figure $9 \mathrm{~b}$ ) took the incompletely dissolved precipitates at grain or lath boundaries as the core of nucleation and growth by diffusional transformation in the first stage, and then coarse austenite with straight interface (marked by arrows in Figure 9a) was formed by martensitic reverse transformation within martensite laths [79]. In particular, the precipitates with low thermal stability in interior of martensite lath were almost completely dissolved after thermal simulation, as shown in Figure 9a, which also reduced the resistance to martensitic $\alpha / \gamma$ reverse transformation within martensite laths [87]. The diffusion modes of solute atom in the matrix mainly included lattice diffusion and short-circuit diffusion [88], and the latter took crystal defects, i.e., grain boundary and dislocation, as the diffusion path. The diffusion rate of solute atom in crystal defects is several orders of magnitude higher than that in lattice and short-circuit diffusion is an effective way of atomic diffusion. Boron atoms with small radius tended to cluster at the grain boundary due to the adsorption of the grain boundary and dislocation [89]. Abe [90] found the accumulation of boron at grain boundaries in 9Cr-B steel, and Wang and He [91] also found similar results in boron modified low carbon bainitic steels. Martensite lath boundary was also a crystal defect where boron might accumulate. We [79,80] proposed a model in which boron promoted austenite memory effect by occupying dislocation channels and blocking diffusional phase transformation, as diagrammatized in Figure 9c. Under the condition of rapid heating in welding, the stacking boron atoms in dislocation channels cannot diffuse away in time, which hindered the diffusion of other solute atoms, leading to martensitic $\alpha / \gamma$ reverse transformation and austenite memory effect in FB2 steel. In addition, martensitic $\alpha / \gamma$ reverse transformation was also found in Fe-Ni-Co alloys [92]. It was reported that the stacking fault zone in maraging steel was beneficial for martensitic $\alpha / \gamma$ reverse transformation [93-95]. Co could lower stacking fault energy of the martensite matrix [95,96] and retard diffusion by raising Curie-temperature [97], which might contribute to martensitic $\alpha / \gamma$ reverse transformation and austenite memory effect. 
(a)
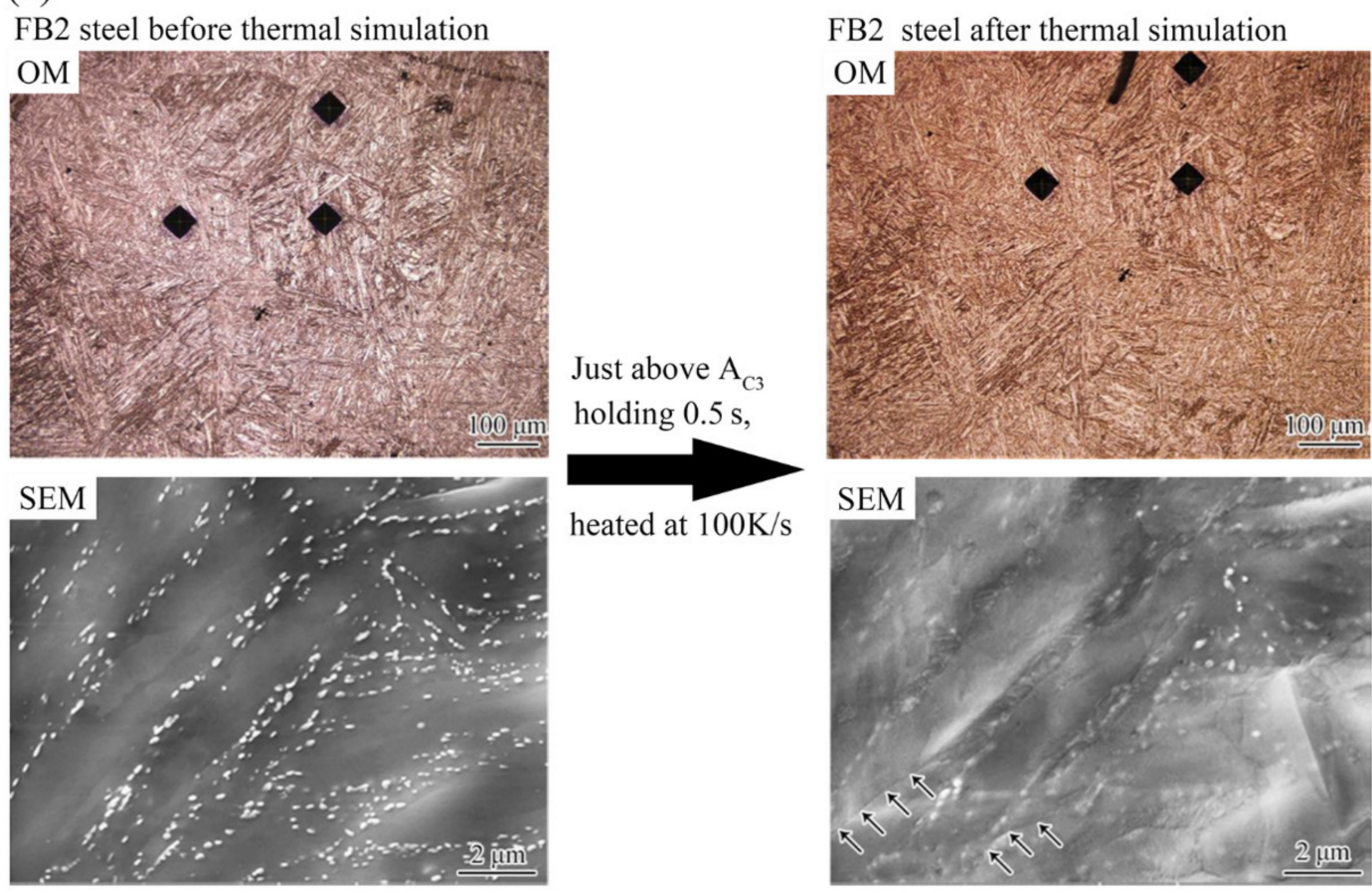

(b)

FB2 steel after thermal simulation

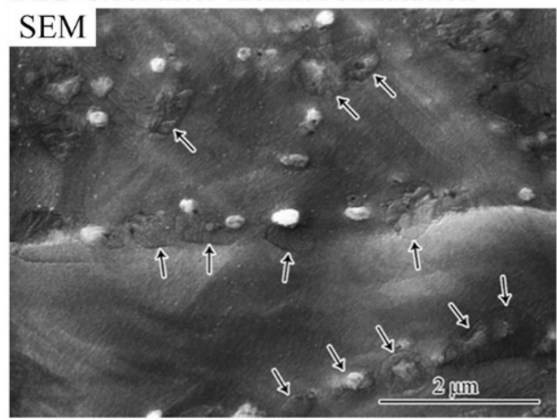

(c)

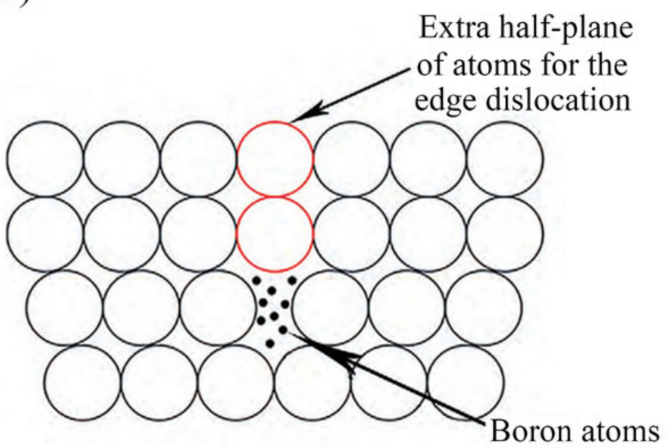

Figure 9. Austenite memory effect in HAZ of FB2 steel [80]: (a) OM and SEM images of the same location before and after $A_{C 3} \mathrm{HAZ}$ thermal simulation (The arrows show the straight interface within martensite lath), (b) SEM image after $A_{C 3}$ HAZ thermal simulation (The arrows show the rounded interface at boundaries of prior austenite and martensite lath), and (c) schematic diagram for the distribution of boron atoms in the lattice under rapid heating.

In addition to the models of boron facilitating martensitic $\alpha / \gamma$ reverse transformation, some researchers believed that boron promoted austenite memory effect by improving the stability of the precipitates, i.e., the theory of Das et al. [75,76]. Under a certain thermodynamic condition, small size precipitates dissolve and large size precipitates grow, which satisfies the need to reduce the total free energy of the system. After small size precipitates dissolve, some alloy atoms enter the interstitial sites in matrix, and new vacancies are formed and they will diffuse around large size precipitates to provide the enrichment locations for alloy atoms, resulting in the continued growth of large size precipitates. In 9Cr-B steel, boron atoms preferentially occupied the vacancies around precipitates due to their strong diffusion ability, preventing other alloy atoms from accumulating around the precipitates, which inhibited the precipitates from coarsening [71], as shown in Figure 10. Boron atoms accumulated at martensite lath boundary because of the adsorption of grain boundary and dislocation [72,79,89,98,99], which inhibited the coarsening of precipitates at the martensite lath boundary. Das et al. [75,76] believed 
that boron-stabilized precipitates at martensite lath boundaries led to the diffusional reconstitution of prior austenite, as mentioned in Section 2.2.

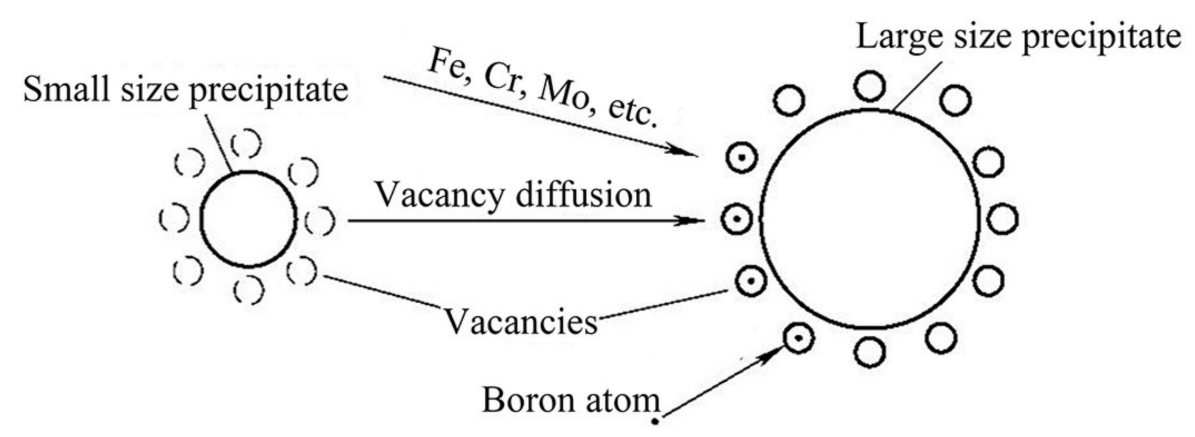

Figure 10. Schematic diagram for boron blocking precipitate coarsening [86].

\subsection{Matrix Microstructure}

Shirane et al. [70] and Abe et al. [72] modified the retained austenite in conventional martensitic steel and $9 \mathrm{Cr}$-B steel by heat treatment and investigated the microstructure evolution of these steels in $A_{C 3}$ HAZ thermal simulation to clarify the effect of matrix microstructure on austenite memory effect. As we know, normalized sub-zone of Gr.92 HAZ was composed of fine grains which were formed by diffusional $\alpha / \gamma$ reverse transformation. If the tempering process for Gr.92 was omitted, $3.1 \%$ retained austenite existed in its matrix. During $A_{C 3}$ HAZ thermal simulation of Gr.92 containing retained austenite, $\alpha / \gamma$ reverse transformation was achieved by the diffusional growth and coalescence of retained austenite, leading to the reconstruction of prior austenite [70]. The different austenization of Gr.92 with and without retained austenite implied that the retained austenite could promote austenite memory effect in normalized sub-zone of martensitic steel HAZ. As described in Section 2.3, omitting the tempering process of 130B 9Cr-3W-3Co steel resulted in retained austenite in matrix and the austenitization process in $A_{\mathrm{C} 3} \mathrm{HAZ}$ would be dominated by the diffusional growth and coalescence of retained austenite [70]. Although both 130B 9Cr-3W-3Co steel with and without retained austenite formed coarse austenite during the $A_{C 3} \mathrm{HAZ}$ thermal simulation, the former was controlled by diffusion and the later by shear. Therefore, the matrix microstructure at room temperature, here referring to presence or absence of retained austenite, could affect the formation of coarse austenite and change the mechanism of austenite memory effect.

\subsection{Heating Condition}

We $[79,80]$ experimentally investigated the influences of heating rate, peak temperature and holding time at peak temperature on the austenitization of FB2 steel, and found that heating condition could affect austenite memory effect. Figure 11 shows the microstructure at the same location in FB2 before and after thermal simulation. In addition, thermal simulated samples were tempered at $680{ }^{\circ} \mathrm{C}$ for $2 \mathrm{~h}$ to make the dissolved alloying atoms precipitate and then were grinded, polished and chemically etched again to get more microstructure information. As mentioned in Section 3.1, austenite memory effect would occur in $A_{C 3} \mathrm{HAZ}$ of FB2, which was verified by the $A_{C 3} \mathrm{HAZ}$ thermal simulation of heating FB2 steel to $1000{ }^{\circ} \mathrm{C}$ (just above $A_{C 3}$ ) with holding $0.5 \mathrm{~s}$ at a heating rate of $100{ }^{\circ} \mathrm{C} / \mathrm{s}$, as shown in Figure 9a. Decreasing heating rate to $5^{\circ} \mathrm{C} / \mathrm{s}$ or even $1{ }^{\circ} \mathrm{C} / \mathrm{s}$ with the peak temperature of $1000{ }^{\circ} \mathrm{C}$ and the holding time of $0.5 \mathrm{~s}$, although the orientation and microstructural characteristics of martensite lath at some locations were not significantly changed, the boundaries of original prior austenite and martensite lath became blurred, and fine austenite was also found in interior of prior austenite, which indicated that austenite memory effect was partially broken, as shown in Figure 11. At the low heating rate of $5^{\circ} \mathrm{C} / \mathrm{s}$ and $1^{\circ} \mathrm{C} / \mathrm{s}$, the boron atoms occupying the dislocation channels could diffuse away, as shown in Figure 12a, making the obstruction to diffusional phase transformation disappear, and thus the whole $\alpha / \gamma$ reverse transformation in FB2 steel was controlled by diffusion and 
fine austenite could nucleate and grow in the interior of prior austenite [79]. After thermal simulation under slow heating condition $\left(5^{\circ} \mathrm{C} / \mathrm{s}\right.$ and $\left.1{ }^{\circ} \mathrm{C} / \mathrm{s}\right)$, the retention of the original boundaries of prior austenite and martensite lath was due to boron improving the stability of precipitate at these sites to enable the boundaries to be better nailed [79]. Boron atoms tended to cluster at boundaries of prior austenite and martensite lath $[71,89,98,99]$ and could inhibit the precipitates at these sites from coarsening by enhancing their stability [71]. The precipitate could occupy a certain length of grain boundary, and the total interface length was the sum of the precipitate perimeter and the actual grain boundary length, as diagrammatized in Figure 12b. The total interface length was minimized when the actual grain boundary passed through the two ends of the precipitate diameter, which met the requirement of the lowest interface energy, resulting in the grain boundary being effectively nailed [100]. In addition, during the thermal simulation, the highly stable precipitates at the boundaries of the prior austenite and martensite lath were difficult to dissolve completely, and in the subsequent tempering process, the newly-formed precipitates would take the incompletely-dissolved precipitates as the sites of nucleation and grow up, which might also play a role in reappearing of the original prior austenite boundary and martensite lath boundary [79].

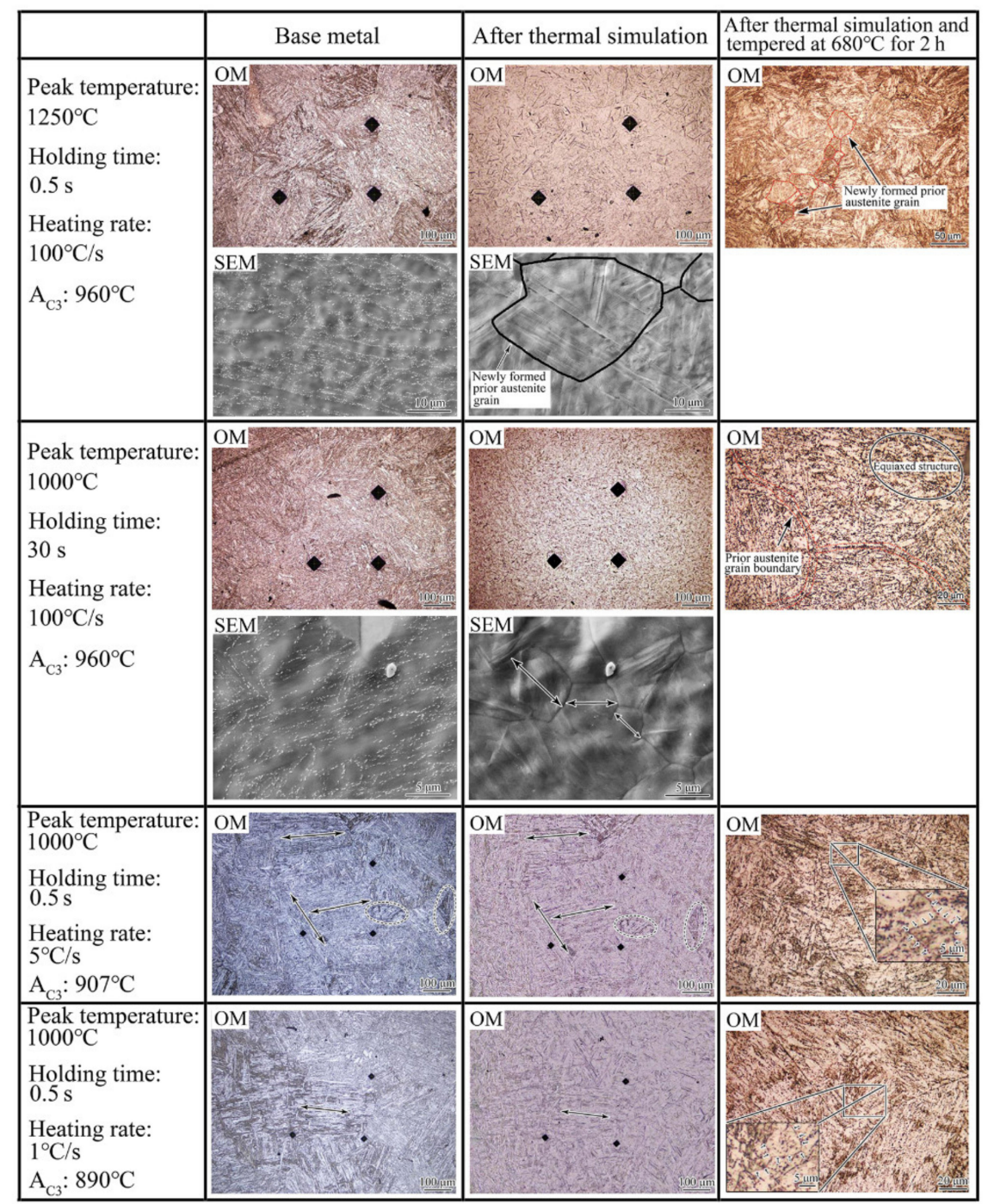

Figure 11. OM and SEM images of FB2 steel for the same location before and after the thermal simulation (not grinded, polished, and chemically etched again), and for a certain location after the thermal simulation and tempering at $680{ }^{\circ} \mathrm{C}$ for $2 \mathrm{~h}$ (grinded, polished and chemically etched again) $[79,80]$. 
(a) Extra half-plane of atoms for the edge dislocation

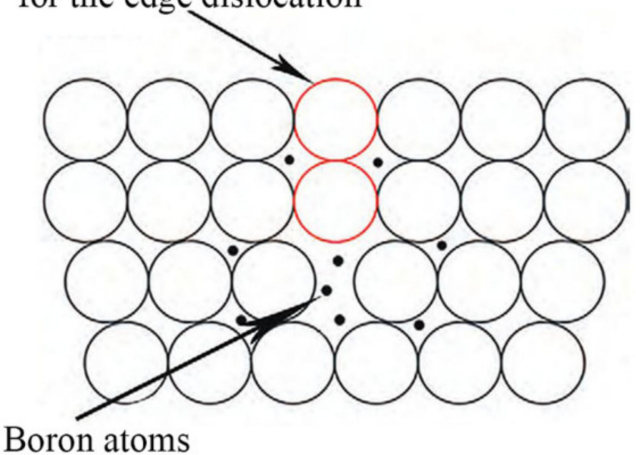

(b)

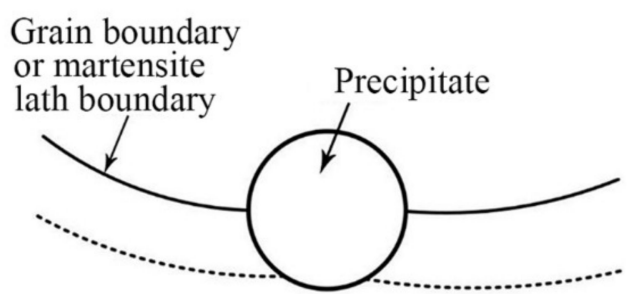

Figure 12. (a) Boron distribution in FB2 matrix under slow heating condition [80] and (b) the pinning effect of precipitate on grain boundary or martensite lath boundary [79].

In the opinion of Apple and Krauss [87], the $\alpha / \gamma$ reverse transformation controlled by short-range diffusion was capable of changing into martensitic $\alpha / \gamma$ reverse transformation at a certain high heating rate. The criterion for distinguishing short-range diffusion from long-range diffusion was as follows [101]

$$
\dot{R}>10^{8} \mathrm{~cm}^{-1} \times D
$$

where $R$ is the advancing interface rate of newly formed phase and $D$ the diffusion coefficient in matrix of the solute species under consideration. When the above relationship is satisfied, diffusion is short-range; otherwise long-range. The main alloy elements in FB2 steel are $\mathrm{Cr}, \mathrm{Mo}, \mathrm{V}, \mathrm{Nb}$, and C, in which Mo and part of $\mathrm{Cr}$ exist in matrix as solid solution atoms, while $\mathrm{V}, \mathrm{Nb}$, and $\mathrm{C}$ mainly exist in the form of precipitated phases. Mo and $\mathrm{Cr}$ are ferrite stabilizers and diffuse from austenite to martensite during austenitization. We [80] used a confocal scanning laser microscope to measure the $\gamma$ advancing interface rate of $5.57 \mu \mathrm{m} / \mathrm{s}$ during $\alpha / \gamma$ reverse transformation of FB2 steel at heating rate of $5{ }^{\circ} \mathrm{C} / \mathrm{s}$. Picking the diffusion coefficient of Mo and $\mathrm{Cr}$ of $1 \times 10^{-12} \mathrm{~cm}^{2} / \mathrm{s}$ and $5 \times 10^{-13} \mathrm{~cm}^{2} / \mathrm{s}$ reported in simply alloyed $\gamma-\mathrm{Fe}$ at $908^{\circ} \mathrm{C}$ (corresponding to $A_{\mathrm{C} 3}$ at heating rate of $5{ }^{\circ} \mathrm{C} / \mathrm{s}$ ) [102], the $\gamma$ advancing interface rate of $5.57 \mu \mathrm{m} / \mathrm{s}$ was greater than $10^{8} \mathrm{~cm}^{-1} \times D$, indicating the dominance of short-range diffusion in $\alpha / \gamma$ reverse transformation of $\mathrm{FB} 2$ steel at heating rate of $5{ }^{\circ} \mathrm{C} / \mathrm{s}$. It means that $\alpha / \gamma$ reverse transformation in FB2 would be martensitic at high heating rate, which was consistent with the experimental results of FB2 steel at heating rate of $100^{\circ} \mathrm{C} / \mathrm{s}$.

Some other researchers also investigated the effects of heating rate on austenite memory effect. Kessler and Pitsch [103] studied $\alpha / \gamma$ reverse transformation in Fe-Ni alloy with heating rate ranging from $100{ }^{\circ} \mathrm{C} / 10 \mathrm{~min}$ to $100{ }^{\circ} \mathrm{C} / \mathrm{s}$ and they found that $\alpha$ martensitically transformed to $\gamma$ at high heating rate, and only part of $\alpha$ martensitically transformed to $\gamma$ at low heating rate because $\mathrm{Fe}$ and $\mathrm{Ni}$ diffused across the phase interfaces and stabilized the rest of $\alpha$. Apple and Krauss [87] investigated the austenitization processes of a series of $\mathrm{Fe}-\mathrm{Ni}-\mathrm{C}$ alloys with carbon contents of 0.004 , $0.05,0.3$, and $0.6 \mathrm{wt} . \%$ under heating rates between about 3 and $28,000{ }^{\circ} \mathrm{C} / \mathrm{s}$ and found that $\alpha / \gamma$ reverse transformation in these alloys could be dominated by shear at very high heating rate. It was reasonably concluded that austenite memory effect might occur in most steels at extremely high critical heating rate (perhaps much higher than the welding heating rate) because diffusion could not be achieved and $\alpha / \gamma$ reverse transformation could only be accomplished by shear. The critical heating rates over which austenite memory effect occurs are different for different steels due to their different chemical compositions. Here we propose that boron plays an important role in lowering the critical heating rate, namely promoting austenite memory effect. For NIMS 130B 9Cr-3W-3Co steel with $130 \mathrm{ppm}$ boron, martensitic $\alpha / \gamma$ reverse transformation occurred at the heating rate of $5^{\circ} \mathrm{C} / \mathrm{s}$ [70]; for FB2 steel with 80-100 ppm boron, the critical heating rate for martensitic $\alpha / \gamma$ reverse transformation was higher than $5{ }^{\circ} \mathrm{C} / \mathrm{s}$ but lower than $100^{\circ} \mathrm{C} / \mathrm{s}$ [79]; for T/P92 steel with $20-40 \mathrm{ppm}$ boron, $\alpha / \gamma$ reverse transformation at 
the welding heating rate (higher than $100^{\circ} \mathrm{C} / \mathrm{s}$ ) was controlled by diffusion rather than shear, and there was still grain refinement in their HAZs [64,66,104-107].

Except for heating rate, peak temperature and holding time at peak temperature also affect the austenite memory effect strongly. In our experiment, increasing the peak temperature to $1250{ }^{\circ} \mathrm{C}$ with the holding time of $0.5 \mathrm{~s}$ and the heating rate of $100^{\circ} \mathrm{C} / \mathrm{s}$, or extending the holding time to $30 \mathrm{~s}$ with the peak temperature of $1000{ }^{\circ} \mathrm{C}$ and the heating rate of $100{ }^{\circ} \mathrm{C} / \mathrm{s}$, the original prior austenite boundary and martensite lath boundary disappeared, precipitates dissolved, and fine grained austenite formed, as shown in Figure 11, implying the disappearance of austenite memory effect. The dislocation density of austenite formed by shear was higher than that by diffusion, indicating the higher distortion energy of the former [108]. For FB2 steel, fine austenite formed by diffusion at martensite lath boundary had lower dislocation density and distortion energy than coarse austenite formed by shear within martensite lath under a rapid heating condition; if peak temperature was increased or the holding time at peak temperature extended, the decrease of distortion energy caused by dislocation annihilation was higher than the increase of interface energy, which meant that the total energy of the system was reduced, and thus the austenite with low dislocation density at martensite lath boundary would devour the austenite with high dislocation density within martensite lath by diffusion $[79,80]$. Subsequently, the growing adjacent austenite at a martensite lath boundary impinged and the lath-like austenite would be segmented and fragmented [79,80], as shown in Figure 13. Lee et al. [108] also found that in $\mathrm{Fe}-0.023 \%, \mathrm{C}-10.91 \%, \mathrm{Cr}-9.23 \%$, Ni- $6.97 \%$, and $\mathrm{Mn}$ steel, the austenite of high dislocation density would transform into the austenite of low dislocation density by the extension of holding time. Therefore, decreasing heating rate, increasing peak temperature or extending holding time at peak temperature could partially or completely break austenite memory effect in FB2 steel, which implied that heating condition might affect austenite memory effect in 9Cr-B steel.

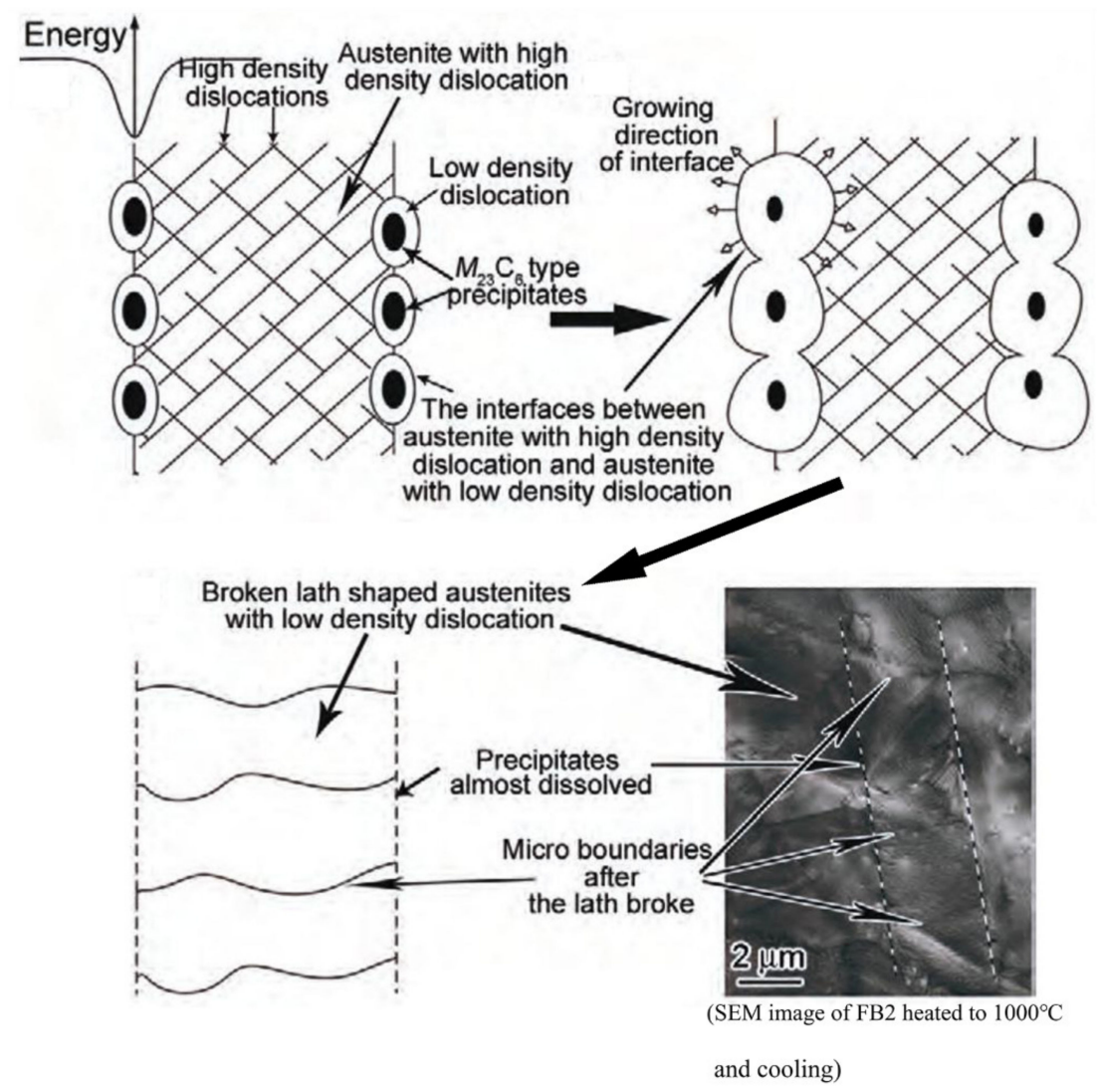

Figure 13. Schematic diagram of microstructure evolution of FB2 steel under the higher peak temperature than $A_{\mathrm{C} 3}$ or the longer holding time at peak temperature than $0.5 \mathrm{~s}$ [80]. 


\section{Conclusions}

In the present article, austenite memory effect in HAZ of B containing $9 \% \mathrm{Cr}$ martensitic heat-resistant steel was reviewed. The addition of boron suppressed the grain refinement and promoted the formation of coarse austenite in normalized sub-zone of HAZ, which resulted from the austenite memory effect during welding. Although it was considered that diffusional nucleation of fine austenite at grain boundary was the first stage of reverse transformation in $9 \mathrm{Cr}-\mathrm{B}$ steel HAZ, two different types of formation mechanisms of coarse austenite in interior of grain, martensitic reverse transformation and diffusional reverse transformation, were proposed. There were two main models in which boron facilitated martensitic $\alpha / \gamma$ reverse transformation leading to austenite memory effect: (i) The segregation of boron at grain boundary reduced grain boundary energy and thus inhibited heterogeneous nucleation at these sites, retarding diffusional phase transformation; (ii) boron atoms accumulated in dislocation channels and could not diffuse away under rapid heating, hindering diffusion of other solute atoms. There was also a model that boron improved stability of the precipitates at martensite lath boundary and $\gamma$ grew along martensite lath by diffusion, leading to the reconstitution of prior austenite. The presence of retained austenite in matrix could induce austenite memory effect and change the formation mechanism of coarse austenite from shear to diffusion. In addition, decreasing heating rate, increasing peak temperature or extending holding time at peak temperature could partially or completely break austenite memory effect in 9Cr-B steel.

Author Contributions: Writing—original draft preparation, X.L.; review and editing, X.L. and K.L.; validation, Z.C.; supervision, Z.C. and J.P.; project administration, Z.C. and J.P.

Funding: This research was funded by National Natural Science Foundation of China [Project 51775300 and 51901113].

Acknowledgments: Shanghai Turbine Company, Shanghai, China and State Key Laboratory of Tribology, Beijing, China.

Conflicts of Interest: The authors declare no conflict of interest.

\section{References}

1. Kimura, H.; Sato, T.; Bergins, C.; Imano, S.; Saito, E. Development of technologies for improving efficiency of large coal-fired thermal power plants. Hitachi Rev. 2011, 60, 365-371.

2. Bugge, J.; Kjær, S.; Blum, R. High-efficiency coal-fired power plants development and perspectives. Energy 2006, 31, 1437-1445. [CrossRef]

3. Abe, F. Research and development of heat-resistant materials for advanced USC power plants with steam temperatures of $700{ }^{\circ} \mathrm{C}$ and above. Engneering 2015, 1, 211-224. [CrossRef]

4. Abe, F.; Taneike, M.; Sawada, K. Alloy design of creep resistant $9 \mathrm{Cr}$ steel using a dispersion of nano-sized carbonitrides. Int. J. Press. Vessel. Pip. 2007, 84, 3-12. [CrossRef]

5. Babu, S.H.; Amarendra, G.; Rajaraman, R.; Sundar, C.S. Microstructural Characterization of Ferritic/Martensitic Steels by Positron Annihilation Spectroscopy. J. Physics: Conf. Ser. 2013, 443, 012010. [CrossRef]

6. Coussement, C.; Dhooge, A.; De Witte, M.; Dobbelaere, R.; Van Der Donckt, E. High temperature properties of improved 9\% Cr steel weldments. Int. J. Press. Vessel. Pip. 1991, 45, 163-178. [CrossRef]

7. Ennis, P.J;; Czyrska-Filemonowicz, A. Recent advances in creep-resistant steels for power plant applications. Sadhana 2003, 28, 709-730. [CrossRef]

8. Pandey, C.; Mahapatra, M.M.; Kumar, P.; Giri, A. Microstructure characterization and charpy toughness of P91 weldment for as-welded, post-weld heat treatment and normalizing \& tempering heat treatment. Met. Mater. Int. 2017, 23, 900-914.

9. Pandey, C.; Giri, A.; Mahapatra, M.M.; Kumar, P. Characterization of microstructure of HAZs in as-welded and service condition of P91 pipe weldments. Met. Mater. Int. 2017, 23, 148-162. [CrossRef]

10. Silwal, B.; Li, L.; Deceuster, A.; Griffiths, B. Effect of postweld heat treatment on the toughness of heat-affected zone for Grade 91 steel. Weld. J. 2013, 92, 80S-87S. 
11. Zhang, Y.; Li, K.; Cai, Z.; Pan, J. Creep rupture properties of dissimilar metal weld between Inconel 617B and modified 9\%Cr martensitic steel. Mater. Sci. Eng. A 2019, 764, 138189. [CrossRef]

12. Abson, D.J.; Rothwell, J.S. Review of type IV cracking of weldments in $9-12 \%$ Cr creep strength enhanced ferritic steels. Int. Mater. Rev. 2013, 58, 437-473. [CrossRef]

13. Falat, L.; Svoboda, M.; Výrostková, A.; Petryshynets, I.; Sopko, M. Microstructure and creep characteristics of dissimilar T91/TP316H martensitic/austenitic welded joint with Ni-based weld metal. Mater. Charact. 2012, 72, 15-23. [CrossRef]

14. Lee, J.S.; Maruyama, K. Mechanism of microstructural deterioration preceding type IV failure in weldment of Mod.9Cr-1Mo steel. Met. Mater. Int. 2015, 21, 639-645. [CrossRef]

15. Shin, K.Y.; Lee, J.W.; Han, J.M.; Lee, K.W.; Kong, B.O.; Hong, H.U. Transition of creep damage region in dissimilar welds between Inconel 740H Ni-based superalloy and P92 ferritic/martensitic steel. Mater. Charact. 2018, 139, 144-152. [CrossRef]

16. Matsui, M.; Tabuchi, M.; Watanabe, T.; Kubo, K.; Kinugawa, J.; Abe, F. Degradation of Creep Strength in Welded Joint of 9\%Cr Steel. ISIJ Int. 2001, 41, 126-130. [CrossRef]

17. Albert, S.; Matsui, M.; Watanabe, T.; Hongo, H.; Kubo, K.; Tabuchi, M. Variation in the Type IV cracking behaviour of a high Cr steel weld with post weld heat treatment. Int. J. Press. Vessel. Pip. 2003, 80, 405-413. [CrossRef]

18. Francis, J.A.; Mazur, W.; Bhadeshia, H.K.D.H. Type IV cracking in ferritic power plant steels. Mater. Sci. Technol. 2006, 22, 1387-1395. [CrossRef]

19. Hirata, H.; Ogawa, K. Relationship between deterioration of creep rupture strength and microstructure in heat affected zone of heat resistant ferritic steel. Weld. Int. 2005, 19, 109-117. [CrossRef]

20. Xue, W.; Pan, Q.-G.; Ren, Y.-Y.; Shang, W.; Zeng, H.-Q.; Liu, H. Microstructure and type IV cracking behavior of HAZ in P92 steel weldment. Mater. Sci. Eng. A 2012, 552, 493-501. [CrossRef]

21. Zhang, Q.B.; Zhang, J.X.; Zhao, P.F.; Huang, Y.; Yang, Y.; Zhao, Y.L. Microstructure of $10 \%$ Cr martensitic heat-resistant steel welded joints and type IV cracking behavior during creep rupture at $650{ }^{\circ} \mathrm{C}$. Mater. Sci. Eng. A 2015, 638, 30-37. [CrossRef]

22. Li, X.; Cabrillat, M.T.; Lejeail, Y. Study of Modified 9Cr-1Mo Welds. Available online: https://inis.iaea.org/ search/search.aspx?orig_q=RN:43024030 (accessed on 31 November 2006).

23. Pandey, C.; Mahapatra, M.M.; Kumar, P.; Saini, N. Some studies on P91 steel and their weldments. J. Alloy. Compd. 2018, 743, 332-364. [CrossRef]

24. Albert, S.K.; Matsui, M.; Watanabe, T.; Hongo, H.; Kubo, K.; Tabuchi, M. Microstructural Investigations on Type IV Cracking in a High Cr Steel. ISIJ Int. 2002, 42, 1497-1504. [CrossRef]

25. Li, D.; Shinozaki, K.; Kuroki, H.; Harada, H.; Ohishi, K. Analysis of factors affecting type IV cracking in welded joints of high chromium ferritic heat resistant steels, Sci. Technol. Weld. Join. 2003, 8, 296-302. [CrossRef]

26. Abe, F.; Tabuchi, M. Microstructure and creep strength of welds in advanced ferritic power plant steels. Sci. Technol. Weld. Join. 2004, 9, 22-30. [CrossRef]

27. Letofsky, E.; Cerjak, H. Metallography of $9 \mathrm{Cr}$ steel power plant weld microstructures. Sci. Technol. Weld. Join. 2004, 9, 31-36. [CrossRef]

28. Li, D.; Shinozaki, K.; Harada, H.; Ohishi, K. Investigation of precipitation behavior in a weld deposit of 11Cr-2W ferritic steel. Met. Mater. Trans. A 2005, 36, 107-115. [CrossRef]

29. Li, D.; Shinozaki, K. Simulation of role of precipitate in creep void occurrence in heat affected zone of high Cr ferritic heat resistant steels, Sci. Technol. Weld. Join. 2005, 10, 544-549. [CrossRef]

30. Liu, Y.; Tsukamoto, S.; Shirane, T.; Abe, F. Formation Mechanism of Type IV Failure in High Cr Ferritic Heat-Resistant Steel-Welded Joint. Met. Mater. Trans. A 2013, 44, 4626-4633. [CrossRef]

31. Laha, K.; Chandravathi, K.; Parameswaran, P.; Rao, K.B.S.; Mannan, S. Characterization of Microstructures across the Heat-Affected Zone of the Modified 9Cr-1Mo Weld Joint to Understand Its Role in Promoting Type IV Cracking. Met. Mater. Trans. A 2007, 38, 58-68. [CrossRef]

32. Esposito, L. Type IV creep cracking of welded joints: Numerical study of the grain size effect in HAZ. Procedia. Struct. Integr. 2016, 2, 919-926. [CrossRef]

33. Pandey, C.; Mahapatra, M.; Kumar, P.; Kumar, S.; Sirohi, S. Effect of post weld heat treatments on microstructure evolution and type IV cracking behavior of the P91 steel welds joint. J. Mater. Process. Technol. 2019, 266, 140-154. [CrossRef] 
34. Masuyama, F. Advance Power Plant Developments and Materials Experience in Japan. In Proceedings of the 8th Liege Conference on Materials for Advanced Power Engineering, Liege, Belgium, 18-20 September 2006; Volume 53, pp. 175-187.

35. Viswanathan, R.; Purget, R.; Rao, U. Materials Technology Foradvanced Coal Power Plants; Springer: Berlin, Germany, 2005; Available online: www.phase-trans.msm.cam.ac.uk/2005/LINK/188.pdf.

36. Horiuchi, T.; Igarashi, M.; Abe, F. Improved Utilization of Added B in 9Cr Heat-Resistant Steels Containing W. ISIJ Int. 2002, 42, 67-71. [CrossRef]

37. Abe, F.; Horiuchi, T.; Taneike, M.; Sawada, K. Stabilization of martensitic microstructure in advanced $9 \mathrm{Cr}$ steel during creep at high temperature. Mater. Sci. Eng. A 2004, 378, 299-303. [CrossRef]

38. Semba, H.; Abe, F. Alloy design and creep strength of advanced $9 \% \mathrm{Cr}$ USC boiler steels containing high concentration of boron. Energy Mater. 2006, 1, 238-244. [CrossRef]

39. Abe, F. Analysis of creep rates of tempered martensitic $9 \% \mathrm{Cr}$ steel based on microstructure evolution. Mater. Sci. Eng. A 2009, 510, 64-69. [CrossRef]

40. Abe, F. Creep Strain Behavior in Transient Region and Minimum Creep Rate of Tempered Martensitic $9 \% \mathrm{Cr}$ Steel. Mater. Sci. Forum 2010, 638, 47-52. [CrossRef]

41. Liu, Y.; Tsukamoto, S.; Sawada, K.; Tabuchi, M.; Abe, F. Precipitation Behavior in the Heat-Affected Zone of Boron-Added 9Cr-3W-3Co Steel During Post-Weld Heat Treatment and Creep Deformation. Met. Mater. Trans. A 2015, 46, 1843-1854. [CrossRef]

42. Liu, Y.; Tsukamoto, S.; Sawada, K.; Abe, F. Role of boundary strengthening on prevention of type IV failure in high Cr ferritic heat-resistant steels. Metall. Mater. Trans. A 2014, 45, 1306-1314. [CrossRef]

43. Suzuki, S.; Shishido, R.; Tanaka, T.; Abe, F. Characterization of the Inhomogeneous Distribution of Light Elements in Ferritic Heat-Resistant Steels by Secondary Ion Mass Spectrometry. ISIJ Int. 2014, 54, 885-892. [CrossRef]

44. Abe, F. Progress in Creep-Resistant Steels for High Efficiency Coal-Fired Power Plants. J. Press. Vessel. Technol. 2016, 138, 040804. [CrossRef]

45. Shirane, T.; Shimizu, M.; Tsukamoto, S.; Tsuzaki, K.; Adachi, Y.; Hanamura, T.; Abe, F. Reverse transformation behaviour in $\mathrm{B}$ containing high $\mathrm{Cr}$ heat resistant steel HAZ. In Proceedings of the 8th International Conference, Trends in Welding Research, Pine Mountain, GA, USA, 1-6 June 2008; p. 284.

46. Shirane, T.; Abe, F. Prevention of type IV failure in high $\mathrm{Cr}$ ferritic heat resistant steel welded joint. In Proceedings of the 8th International Conference, Trends in Welding Research, Pine Mountain, GA, USA, 1-6 June 2008; pp. 296-302.

47. Abe, F. Behavior of boron in $9 \mathrm{Cr}$ heat resistant steel during heat treatment and creep deformation. In Key Engineering Materials; Trans Tech Publications: Stafa-Zurich, Switzerland, 2007; pp. 569-572.

48. Abe, F.; Tabuchi, M.; Kondo, M.; Okada, H. Suppression of type IV fracture in welded joints of advanced ferritic power plant steels-effect of boron and nitrogen. Mater. High Temp. 2006, 23, 145-154.

49. Abe, F. Long-term stabilization of creep resistant $9 \mathrm{Cr}$ steel by boron for efficient, low emission power plant at $650^{\circ}$ C. Rev. Metall-Paris 2006, 103, 247-256. [CrossRef]

50. Kern, T.U.; Staubli, M.; Scarlin, B. The European efforts in material development for $650{ }^{\circ} \mathrm{C}$ USC power plants-COST522. ISIJ Int. 2002, 42, 1515-1519. [CrossRef]

51. Shao, C.; Lu, F.; Wang, X.; Ding, Y.; Li, Z. Microstructure characterization and HCF fracture mode transition for modified 9Cr-1Mo dissimilarly welded joint at different elevated temperatures. J. Mater. Sci. Technol. 2017, 33, 1610-1620. [CrossRef]

52. Jandova, D.; Kasl, J. Microstructural changes in weld joint of COST F and FB2 steels after long term creep tests. Mater. High Temp. 2017, 34, 482-491. [CrossRef]

53. Li, K.J.; Cai, Z.P.; Li, Y.F.; Pan, J.L. Constitutional liquation of the laves phase in virgin FB2 steel. Weld. J. 2016, 95, 257S-263S.

54. Li, K.J.; Cai, Z.P.; Pan, J.L. The Evolutionary Behavior of Laves Phase in Virgin FB2 Steel during Welding and Its Effect on Weld Joints. Advances in Materials Technology for Fossil Power Plants. In Proceedings of the Eighth International Conference (EPRI 2016), Algarve, Portugal, 11-14 October 2016; pp. 974-982.

55. Kim, K.-C.; Ma, Y.-W.; Kong, B.-O.; Kim, M.-S.; Kang, S.-T. Effect of strain rate on low cycle fatigue with hold time in 9Cr rotor steel. Mater. Res. Innov. 2013, 17, 332-336. [CrossRef] 
56. Di Gianfrancesco, A.; Cipolla, L.; Paura, M.; Vipraio, S.T.; Venditti, D.; Neri, S.; Calderini, M. The Role of Boron in Long Term Stability of a CrMoCOB (FB2) Steel for Rotor Application. Advances in Materials Technology for Fossil Power Plants. In Proceedings of the Sixth International Conference (EPRI 2010), Sante Fe, NM, USA, 31 Augest-3 September 2010; pp. 342-360.

57. Rothwell, J.; Abson, D. Performance of weldments in advanced 9\%Cr steel-'FB2'. Mater. High Temp. 2010, 27, 253-264. [CrossRef]

58. Sammarco, A.; Thomson, R.C.; Vanstone, R. The Effect of Pre-Service Treatments on the Long Term Properties of $9 \mathrm{Cr}$ Steels Strengthened by Boron and Nitrogen. Advances in Materials Technology for Fossil Power Plants. In Proceedings of the Eighth International Conference (EPRI 2016), Algarve, Portugal, 11-14 October 2016; pp. 568-580.

59. Donth, B.; Blaes, N.; Diwo, A.; Bokelmann, D. New Material and Manufacturing Developments for USC and A-USC Steam Turbine Rotor Forgings. Advances in Materials Technology for Fossil Power Plants. In Proceedings of the Eighth International Conference (EPRI 2016), Algarve, Portugal, 11-14 October 2016; pp. 656-667.

60. Hald, J. Prospects for Martensitic 12 \% Cr Steels for Advanced Steam Power Plants. Trans. Indian Inst. Met. 2016, 69, 183-188. [CrossRef]

61. Albert, S.K.; Kondo, M.; Tabuchi, M.; Yin, F.; Sawada, K.; Abe, F. Improving the creep properties of 9Cr-3W-3Co-NbV steels and their weld joints by the addition of boron. Met. Mater. Trans. A 2005, 36, 333-343. [CrossRef]

62. Abe, F.; Tabuchi, M.; Semba, H.; Igarashi, M.; Yoshizawa, M.; Komai, N.; Fujita, A. Feasibility of MARBN Steel for Application to Thick Section Boiler Component in USC Power Plant at $650{ }^{\circ} \mathrm{C}$. Advances in Materials Technology for Fossil Power Plants. In Proceedings of the 5th International Conference (EPRI 2007), Maroc Island, FL, USA, 3-5; October 2007; pp. 92-106.

63. Abe, F.; Tabuchi, M.; Tsukamoto, S. Metallurgy of type IV fracture in advanced ferritic power plant steels. Mater. High Temp. 2011, 28, 85-94. [CrossRef]

64. Kondo, M.; Tabuchi, M.; Tsukamoto, S.; Yin, F.; Abe, F. Suppressing type IV failure via modification of heat affected zone microstructures using high boron content in $9 \mathrm{Cr}$ heat resistant steel welded joints. Sci. Technol. Weld. Join. 2006, 11, 216-223. [CrossRef]

65. Abe, F.; Tabuchi, M.; Kondo, M.; Tsukamoto, S. Suppression of Type IV fracture and improvement of creep strength of 9Cr steel welded joints by boron addition. Int. J. Press. Vessel. Pip. 2007, 84, 44-52. [CrossRef]

66. Abe, F.; Tabuchi, M.; Kondo, M.; Tsukamoto, S. Improvement of creep strength of advanced ferritic steel welded joints. Weld. World 2005, 49, 59-66. [CrossRef]

67. Law, N.C.; Edmonds, D.V. The formation of austenite in a low-alloy steel. Met. Mater. Trans. A 1980, 11, $33-46$. [CrossRef]

68. Kimmins, S.T.; Gooch, D.J. Austenite memory effect in 1Cr-1Mo-0.75V(Ti,B) steel. Met. Sci. 1983, 17, $519-532$. [CrossRef]

69. Floreen, S. The physical metallurgy of maraging steels. Metall Rev. 1968, 13, 115-128.

70. Shirane, T.; Tsukamoto, S.; Tsuzaki, K.; Adachi, Y.; Hanamura, T.; Shimizu, M.; Abe, F. Ferrite to austenite reverse transformation process in B containing 9\%Cr heat resistant steel HAZ. Sci. Technol. Weld. Join. 2009, 14, 698-707. [CrossRef]

71. Abe, F.; Tabuchi, M.; Tsukamoto, S. Mechanisms for boron effect on microstructure and creep strength of ferritic power plant steels. Energy Mater. 2009, 4, 166-175. [CrossRef]

72. Abe, F.; Tabuchi, M.; Tsukamoto, S.; Shirane, T. Microstructure evolution in HAZ and suppression of Type IV fracture in advanced ferritic power plant steels. Int. J. Press. Vessel. Pip. 2010, 87, 598-604. [CrossRef]

73. Kurdjumov, G.; Sachs, G. Über den Mechanismus der Stahlhärtung. Z. Phys. 1930, 64, 325-343. [CrossRef]

74. Morito, S.; Tanaka, H.; Konishi, R.; Furuhara, T.; Maki, T. The morphology and crystallography of lath martensite in Fe-C alloys. Acta Mater. 2003, 51, 1789-1799. [CrossRef]

75. Das, C.R.; Albert, S.K.; Swaminathan, J.; Raju, S.; Bhaduri, A.K.; Murty, B.S. Transition of Crack from Type IV to Type II Resulting from Improved Utilization of Boron in the Modified 9Cr-1Mo Steel Weldment. Met. Mater. Trans. A 2012, 43, 3724-3741. [CrossRef]

76. Das, C.R.; Bhaduri, A.K.; Lakshmi, S.; Chakravarty, S.; Kar, S.K.; Albert, S.K. Influence of boron and nitrogen on microstructure and hardness of heat-affected zone of modified 9Cr-1Mo steel-Gleeble simulation study. Weld. World 2015, 59, 513-519. [CrossRef] 
77. Liu, L.; Yang, Z.G.; Zhang, C.; Liu, W.B. An in situ study on austenite memory and austenitic spontaneous recrystallization of a martensitic steel. Mater. Sci. Eng. A 2010, 527, 7204-7209. [CrossRef]

78. Liu, L.; Yang, Z.-G.; Zhang, C. Effect of retained austenite on austenite memory of a $13 \% \mathrm{Cr}-5 \%$ Ni martensitic steel. J. Alloy. Compd. 2013, 577, S654-S660. [CrossRef]

79. Li, K.J. Research on the Microstructure Evolutionary Behavior of High Performance Martensitic Heat-Resistant Steel during Welding. Ph.D. Thesis, Tsinghua University, Beijing, China, 2016.

80. Li, K.J.; Cai, Z.P.; Wu, Y.; Pan, J.L. Research on austenite transformation of FB2 heat-resistant steel during welding heating process. Acta Metall. Sin. 2017, 53, 778-788.

81. Abe, F. Effect of boron on creep deformation behavior and microstructure evolution in $9 \% \mathrm{Cr}$ steel at $650{ }^{\circ} \mathrm{C}$. Int. J. Mater. Res. 2008, 99, 387-394. [CrossRef]

82. Maki, T.; Morimoto, H.; Tamura, I. Recrystallization of the Austenite Transformed Reversely and Structure of Martensite in 18Ni Maraging Steel. Tetsu-to-Hagane 1979, 65, 1598-1606. [CrossRef]

83. Santella, M.; Specht, E.; Shingledecker, J.; Abe, F. A Synchrotron Diffraction Study of Transformation Behavior in $9 \mathrm{Cr}$ Steels Using Simulated Weld Heat-affected Zone Conditions. In Proceedings of the 7th International Charles Parsons Turbine Conference, Glasgow, UK, 11-13 September 2007; pp. 427-438.

84. Sakuraya, K.; Okada, H.; Abe, F. BN type inclusions formed in high Cr ferritic heat resistant steel. Energy Mater. 2006, 1, 158-166. [CrossRef]

85. Karlsson, L.; Norden, H. Overview no. 63 Non-equilibrium grain boundary segregation of boron in austenitic stainless steel-II. Fine scale segregation behavior. Acta Metall. 1988, 36, 13-27. [CrossRef]

86. Li, K.J.; Cai, Z.P.; Li, Y.F.; Pan, J.L.; Sun, L.G. Effect of boron on the microstructure and high temperature quasi-static fracture toughness of heat affected zone in heat-resistant steel FB2. J. Mech. Eng. 2015, 24, 69-74. [CrossRef]

87. Apple, C.; Krauss, G. The effect of heating rate on the martensite to austenite transformation in Fe-Ni-C alloys. Acta Met. 1972, 20, 849-856. [CrossRef]

88. Abe, F.; Kern, T.U.; Viswanathan, R. Creep-Resistant Steels; CRC Press: New York, UY, USA, 2008; p. 243.

89. Zhou, Z.F.; Zhang, W.Y. Welding Metallurgy and Metal Weldability, 2nd ed.; Machine Press: Beijing, China, 1988; p. 207.

90. Abe, F. Effect of Boron on Microstructure and Creep Strength ofAdvanced Ferritic Power Plant Steels. Procedia Eng. 2011, 10, 94-99. [CrossRef]

91. Wang, X.M.; He, X.L. Effect of Boron Addition on Structure and Properties of Low Carbon Bainitic Steels. ISIJ Int. 2002, 42, S38-S46. [CrossRef]

92. Colling, D.A. Martensite-to-austenite reverse transformation in Fe-Ni-Co alloys. Met. Mater. Trans. A 1970, 1, 1677-1682. [CrossRef]

93. Zhu, J.; Zhao, Y.W.; Pan, T.X.; Cai, Q.G. Investigation on reverse austenite in $18 \mathrm{Ni}(250$ grade)maraging steel. Iron Steel 1981, 16, 41-45.

94. Cai, Q.G.; Zhu, J.; He, C.Z.; Shen, H.W.; Luo, L.G.; Song, W.S.; Yu, W.L. An investigation of a maraging steel with lower Ni and Co contents. Acta Metall. Sin. 1977, 13, 289-365.

95. Cai, Q.G.; Zhu, J.; He, C.Z. Aging structure of maraging steel. Acta Phys. Sin. Ch. Ed. 1974, 23, $26-41$.

96. Banerjee, B.R.; Hauser, J.J.; Capenos, J.M. Role of Cobalt in the marage-type alloy matrix. Met. Sci. J. 1968, 2, 76-80. [CrossRef]

97. Gustafson, Å.; Ågren, J. Possible Effect of Co on Coarsening of M23C6 Carbide and Orowan Stress in a 9\% Cr Steel. ISIJ Int. 2001, 41, 356-360. [CrossRef]

98. Azuma, T.; Miki, K.; Tanaka, Y.; Ishiguro, T. Effect of B on Microstructural Change during Creep Deformation in High Cr Ferritic Heat Resistant Steel. Tetsu-to-Hagane 2002, 88, 678-685. [CrossRef]

99. Lundin, L.; Fallman, S.; Andren, H.O. Microstructure and mechanical properties of a 10\% chromium steel with improved creep resistance at $600{ }^{\circ} \mathrm{C}$. Mater. Sci. Technol. 1997, 13, 233-242. [CrossRef]

100. Gladman, T. Proceedings of the Royal Society of London A: Mathematical, Physical and Engineering Sciences. R. Soc. 1966, 294, 298-309.

101. Karlyn, D.A.; Cahn, J.W.; Cohen, M. The Massive Transformation in Copper-Zinc Alloys. In The Selected Works of John W. Cahn; TMS: Warrendale, PA, USA, 1969; p. 237.

102. Dayananda, M.A. 6.2 Solutions of Diffusion Equations for Constant Ternary Interdiffusion Coefficients. In Diffusion in Solid Metals and Alloys; Mehrer, H., Ed.; Springer: Berlin/Heidelberg, Germany, 1990; Volume 26, p. 372 . 
103. Kessler, H.; Pitsch, W. On the nature of the martensite to austenite reverse transformation. Acta Metall. 1967, 15, 401-405. [CrossRef]

104. Deng, J.G.; Liang, Z.Y.; Hui, S.E.; Zhao, Q.X. Aging treatment on the microstructures and mechanical properties of new groove T92/Super 304H dissimilar steel joints. High Temp. Mater. Process. 2015, 34, 425-433. [CrossRef]

105. Dunder, M.; Vuherer, T.; Samardzic, I.; Maric, D. Analysis of heat-affected zone microstructures of steel P92 after welding and after post-weld heat treatment. Int. J. Adv. Manuf. Technol. 2019, 102, 3801-3812. [CrossRef]

106. Wang, X.; Xu, Q.; Yu, S.-M.; Liu, H.; Hu, L.; Ren, Y.-Y. Laves-phase evolution during aging in fine grained heat-affected zone of a tungsten-strengthened $9 \% \mathrm{Cr}$ steel weldment. J. Mater. Process. Technol. 2015, 219, 60-69. [CrossRef]

107. Cao, J.; Gong, Y.; Yang, Z.G. Microstructural analysis on creep properties of dissimilar materials joints between T92 martensitic and HR3C austenitic steels. Mater. Sci. Eng. A 2011, 528, 6103-6111. [CrossRef]

108. Lee, S.-J.; Park, Y.-M.; Lee, Y.-K. Reverse transformation mechanism of martensite to austenite in a metastable austenitic alloy. Mater. Sci. Eng. A 2009, 515, 32-37. [CrossRef]

(C) 2019 by the authors. Licensee MDPI, Basel, Switzerland. This article is an open access article distributed under the terms and conditions of the Creative Commons Attribution (CC BY) license (http://creativecommons.org/licenses/by/4.0/). 